\title{
O REGISTRO DE MOLUSCOS NOS VESTÍGIOS ARQUEOLÓGICOS PRÉ-HISTÓRICOS DOBRASIL
}

\section{THE RECORD OF MOLLUSCS IN THE PREHISTORIC ARCHAEOLOGICAL TRACES OF BRAZIL}

\author{
André Prous ${ }^{1}$ e Angelo Pessoa Lima ${ }^{2}$ \\ ${ }^{1}$ Museu de História Natural, Universidade Federal de Minas Gerais. Brasil aprous@gmail.com \\ ${ }^{2}$ Museu de História Natural, Universidade Federal de Minas Gerais. Brasil. \\ lima.angelo@gmail.com
}

Presentado: 27/12/2018 - Aceptado: 15/04/2019

\begin{abstract}
Resumo
Os moluscos foram de grande importância na pré-história brasileira, onde seu papel alimentar foi importante no litoral. Sobretudo, aproveitaram-se suas conchas como material construtivo nos sambaquis costeiros, e para firmar a base dos aterros do Pantanal matogrossense. Elas forneceram instrumentos para cortar, raspar, serrar, perfurar e aplainar, e serviram como recipientes. Também foram utilizadas como adornos (colares, pulseiras, adornos labiais) e proporcionaram elementos para indumentária. A concha moída foi usada como antiplastico nas mais antigas cerâmicas amazônicas. Discutimos o significado das conchas de gastropodo encontradas em sítios interioranos - alguns moluscos foram trazidos pelos pré-históricos, enquanto outros são intrusivos e podem levar a interpretações equivocadas por parte dos arqueólogos.
\end{abstract}

Palavras chaves: Industrias de concha, sambaquis, moluscos na alimentação, conchas em sepultamentos pré-históricos.

\begin{abstract}
Shellfish have been important as a subsistence item in some Brazilian prehistoric coastal cultures, but their shell has also been used as constructive material (in shellmounds along Atlantic Ocean, and as foundation material for the earthmounds built in the Pantanal swamps). The shells have been used as instruments to cut, to scrape, to sew, to drill and to plane. They also provided ornaments (pearl necklaces, bracelets, labrets), clothing and mask accessories, even music instruments. Crushed shell tempered the first Amazonian ceramics found in shellmounds. In this paper, we discuss the significance of mollusk shells in archaeological sediments - some of them brought by humans and others intrusive, because their presence may be misunderstood by the excavator.
\end{abstract}

Keywords: Shell industry, shellmounds, shellfish in alimentation, shells in prehistoric burials. 


\section{Introdução}

Nos sítios arqueológicos restam apenas as conchas dos moluscos; mesmo elas preservam-se apenas em condições especiais, em ambientes de $\mathrm{pH}$ alto. Geralmente, isto corresponde a sedimentos calcitados em abrigos calcários, ao conteúdo de estruturas de combustão (fogueiras, resíduos de queima ricos em cinzas), a depósitos espessos de conchas ou a elementos deixados em bolsões ricos em pigmentos ferruginosos que atuam como conservante.

As conchas encontradas pelos arqueólogos são, por vezes, vestígios de espécimenes que moravam nos sítios e neles morreram naturalmente, enquanto outras vezes elas testemunham de uma dieta que incluía a carne de gastrópodes e bivalves; outras vezes, ainda, trata-se de um material de construção.

No Brasil, as condições favoráveis a sua conservação são particularmente encontradas em sambaquis (que são construções edificadas com conchas acumuladas que podem alcançar vários metros de altura ao longo do litoral atlântico, e até dezenas de metros, no litoral dos estados meridionais do Paraná e de Santa Catarina) ou em "acampamentos" também litorâneos onde as conchas se concentram em bolsões de cinzas e carvões nos quais se misturam diversos resíduos alimentares. Embora menos numerosos, sambaquis fluviais existem também na Amazônia (estados do Amazonas, do Pará e de Rondônia) assim como nos estados meridionais de São Paulo e de Santa Catarina.

Afora isto, os abrigos calcários do Brasil central e nordestino (estados de Minas Gerais e Bahia) e, mais raramente, abrigos em quartzito (Minas Gerais e Piauí), forneceram também restos conchíferos.

\section{Vestígios de subsistência, material de construção, artefatos e presença acidental}

Em alguns casos, pode ser difícil diferenciar os restos alimentares dos instrumentos, dos adornos ou dos animais que viveram e morreram naturalmente nos locais frequentados pelos humanos.

Em meados do século XIX, os amontoamentos de concha mesolíticos (sambaqui no Brasil; kjokkenmodimger na Noruega e na Dinamarca; escargotières na França; shellmounds em países de língua anglosaxônica) eram geralmente considerados naturais - tanto na Europa quanto no Brasil; assim, a presença de restos humanos no meio destes depósitos era considerada acidental. Quando uma comissão foi montada na Dinamarca para debater a possibilidade de serem acumulações produzidas pelas populações pré-históricas, o naturalista W. P. Lund que pesquisava no Brasil informou em 1852 que não haveria duvida da sua origem artificial e indígena (Hoch y Prous 1985). A partir desta data XIX, todos os europeus reconheceram a origem antrópica dos sambaquis. As valvas que os compunham passaram a ser consideradas essencialmente como sendo restos alimentares, embora 
Paulo Duarte - seguindo o pioneiro historiador Francisco Varnhagem - considerasse que estes sítios seriam templos (portanto, construções) edificados em homenagem aos moluscos que constituiam uma verdadeira mana alimentar. Autores como Guilherme Tiburtius (1960), Alan L. Bryan (1977) e Eliana Carvalho (1984) evidenciaram também a utilização das conchas como instrumentos. No limiar do novo milênio, Maria Dulce Gaspar (2000) salientou de novo a função construtiva das conchas, que, para ela, era bem mais importante que seu papel alimentar. De fato, enquanto muitos "concheiros", no mundo inteiro (encontram-se desde a Austrália, até na África do Norte, da Terra do Fogo até os USA e na fachada atlântica da Europa) são essencialmente acumulações de lixo alimentar casualmente usado para recobrir covas funerárias - no Brasil há verdadeiras edificações monumentais. Sem pretender levantar monumentos, outras populações pré-históricas acumulavam conchas em camada de alguns centímetros de espessura em dunas ou em terrenos pantanosos para formar uma base ocupacional seca e estável.

Fora dos sambaquis, o status dos restos conchíferos encontrados é mais difícil de ser estabelecido quando eles não apresentam sinais de modificação voluntária por parte dos pré-históricos. Teriam sido os moluscos trazidos como alimento ou seriam moradores naturais do local, mortos naturalmente? Certas conchas teriam sido coletadas como curiosidade, ou usadas sem preparação como instrumentos? Quando iniciamos as escavações no norte do estado de Minas Gerais, encontramos grandes acumulações de conchas de gastrópodes terrestres (gen. Megalobulimus) inteiras e fragmentadas cobrindo vários metros quadrados e com espessura de até $20 \mathrm{~cm}$. Inicialmente, acreditamos serem restos de alimentação, até que verificamos que estes gastrópodes procuram os abrigos calcários para como fonte de carbonato para fazer suas conchas e neles se enterram perto dos paredões durante a estação seca. Quando as chuvas voltam, saem de novo para o exterior. Por outro lado, encontramos, nos mesmos abrigos, conchas isoladas enterradas nos níveis arqueológicos onde alternam argila, carbonatos e cinzas. Ao penetrar no sedimento, os gastrópodes abriam buracos (posteriormente preenchidos naturalmente) cujas marcas se parecem exatamente com aquelas deixadas por galhos fincados pelos pré-históricos após seu apodrecimento. Por outro lado, como se poderia ter certeza que os moluscos não aproveitaram buracos já deixados por postes inclinados? Muitas conchas foram encontradas em fogueiras, sendo elas queimadas ou intactas. De novo fica a dúvida: será que os animais se enterraram até encontrar as cinzas onde se acomodaram? Ou será que se trata das conchas de caramujos comidos pelos pré-históricos? O fato de a concha ser ou não queimada não esclarece esta dúvida, pois não precisa queimar a concha para recuperar a lesma: basta deixa-la perto do fogo para que ela resseque e se solte, sendo então facilmente retirada da concha. As conchas queimadas, por sua vez, podem ter sido jogadas no fogo voluntariamente para "limpar" o piso ocupacional, ou serem restos de animais enterrados espontaneamente que morreram durante a hibernação. Poderiam então ser recobertas por uma fina camada de sedimento antes de serem casualmente afetadas por uma fogueira instalada encima delas poucos anos depois da sua morte. Mesmo num 
sítio conchífero de tipo sambaqui, pode ser difícil diferenciar a concha de um gastrópode terrestre trazido como alimento daquela de um espécimen que veiou espontaneamente em busca uma fonte de carbonato.
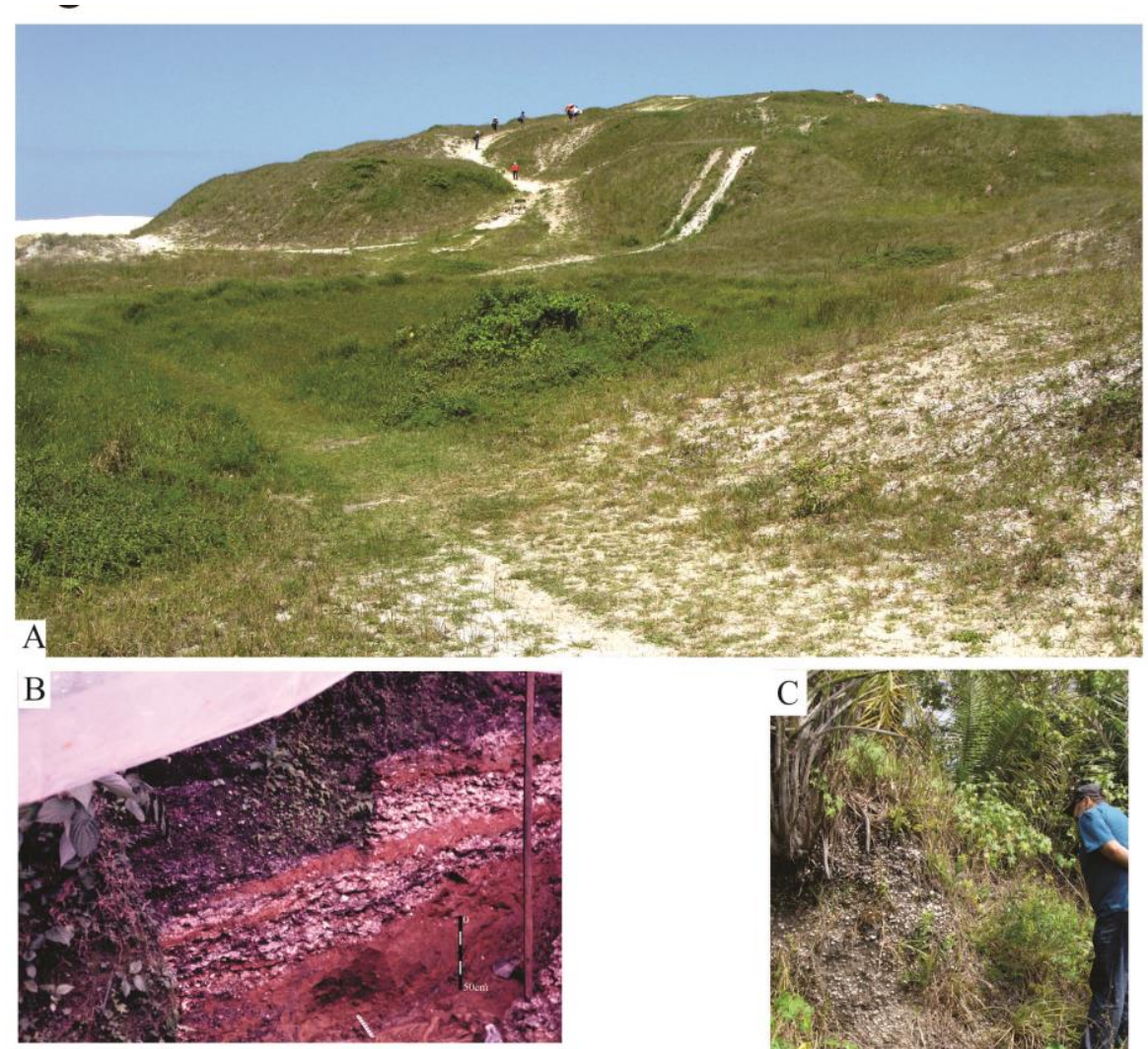

A- Sambaqui de Garopaba, SC; B- Sambaqui da ilha do Casqueirinho, SP (notar o sepultamento em primeiro plano, no centro; C Sambaqui Bacanga, MA.

D - Croqui da estratigrafia do SítioTenório / SP

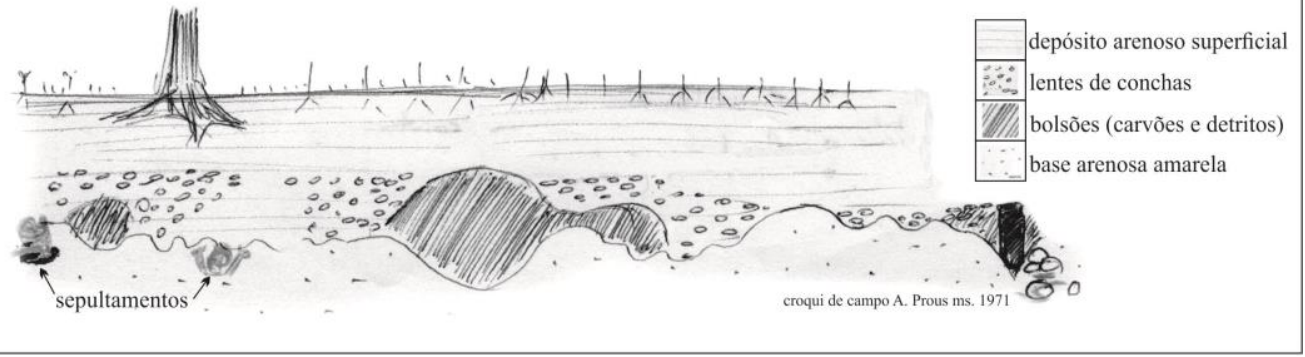

Figura 1. Sitios Conchíferos.

Em muitos sítios pré-históricos litorâneos tardios (datados dos últimos milênios) do Brasil meridional as lentes e bolsões de concha não passam de refugo (por exemplo, nos casqueiros do Tenório - Figura 1, e da Tapera, cf. Rohr e Andreatta, 1969). Mesmo na atualidade, pudemos observar, atrás de habitações de pescadores atuais dos estados de São Paulo e da Bahia, amontoamentos de valvas que podem ter mais de um metro de espessura, pois a coleta de moluscos nunca parou de ser realizada. Contrastando com estes simples depósitos de lixo, os sambaquis são verdadeiras edificações, bem mais altos e com diâmetro de muitas 
dezenas e até algumas centenas de metros. Alguns teriam sido edificados rapidamente (talvez menos de um século para o sambaqui de Piaçaguera, cf. Prous 1992), mas a maioria teria sido levantada ao longo de vários séculos e milênios. Uma preocupação pode ter sido estabelecer um piso firme e seco - seja sobre uma base de areia em praias, seja, mais frequentemente, de lodo em zonas de mangue ou de brejo; isto ocorreu tanto para preparar a edificação de sambaquis quanto para firmar a base de aterros no Pantanal mato-grossense (Schmitz et al. 1998). Acima desta camada isolante progredia a elevação, instalando-se áreas residências e funerárias (Figura 1a y 1b). Enquanto em alguns sambaquis marinhos se sucedem extensas e espessas lentes de conchas, em outros, tal Jabuticabeiras II (Biancchini et al. 2011) e também em sambaquis fluviais, os depósitos de valvas ocorreriam principalmente durante ritos funerários, para cobrir os corpos depositados em áreas específicas.

\section{Os moluscos como alimento}

No litoral brasileiro, o fato de se usar as conchas como material de construção não impediria que se consumissem os moluscos. Estes são muito mais fáceis de se capturar que os vertebrados terrestres ou as aves, e bem mais ricos em gorduras que os peixes. Também suprem carências em ferro para as crianças parasitadas por vermes (informações recebidas de $\mathrm{M}$. de Melo e Alvim). Estudos realizados com Mytilus califonicus nos concheiros da Caliofornia, na América do Norte, indicam que 30 exemplares deste molusco proporcionariam os 40 gramas de proteina necessários diariamente (Erlandson 1988). Pode-se acreditar a análise de moluscos equivalentes dariam reultados parecidos, independentemente das variações sazonais (os valores protéicos se alteram durante o período de reprodução). Assim, os moluscos aquáticos provavelmente tenham desempenhado um papel importante na dieta dos moradores dos sambaquis, pelo menos em ceras estações, mesmo que uma coleta exagerado tenha possivelmente provocado esgotamento periódico de colônias de mexilhões e de ostra.

Nos sambaquis brasileiros, a coleta dominante parece ter sido de berbigão (Anomalocardia brasiliana), de ostras (Crassostrea) e de mexilhões (Mytilus, Modiolus), cujas valvas formam a maior parte do volume dos sambaquis. Contudo, numerosas outras espécies eram consumidas (dos gêneros Macoma, Thais, Astrea, Strombus), etc.; somente nos sambaquis do Paraná, J. J. Bigarella (1949, 1950/51) encontrou 43 espécies de moluscos. Conchas de Pinctata radiata (no estado de São Paulo), Chione (no estado do Maranhão) ou Donax (no estado do Rio Grande do Sul) chegam até a dominar em alguns sítios. Na ilha de Santa Catarina, restos de bivalves foram encontrados em fogões cavadas no meio das conchas e revestidos de argila, que comportavam tampas. Parece que poderiam ter sido preparados e fervidos nestes recipientes fixos. Nos sambaquis fluviais do estado de São Paulo, são as conchas de gastrópodes da família Strophocheilidae que predominam. Também formam a maior parte dos restos de moluscos encontrados nos abrigos do Brasil central (Plens 2007), enquanto os bivalves 
do gênero Diplodon e Pomacea são abundantes nos sítios instalados em zonas lacustres litorâneas (Carvalho 1984) dominando o gênero Pomacea em pântanos interioranos do sudoeste da Amazônia (Miller 2009).

Os moluscos aquáticos estavam disponíveis o ano todo. De fato, a análise das estrias de crescimentos das estrias de crescimento das valvas retiradas de sítios conchiferos pouco espessos nos quais as conchas não eram usadas como material construtivo mostra que eram coletados em qualquer estação na Ilha de Santa Catarina (DeMasi 2001), evidenciando a estabilidade da ocupação nos sítios analizados. Em compensação, os grandes gastrópodes terrestres eram disponíveis apenas na estação das chuvas no Brasil central e nordestino.

Os moluscos forneceram uma parte importante da alimentação para os habitantes do litoral; além de fornecer proteínas, bivalvas como as ostras são uma boa fonte de ferro. Nota-se que sua carne nem sempre fornece proteínas balanceadas, como mostrou a análise do valor nutritivo de Megalobulinus realizadas por membros da nossa equipe (Solá e Jokl 1978). Cozida numa fogueira, a carne desses caramujos forneceu 19,9 \% de proteínas brutas; contudo, nela a Isolucina e a Valina estão em menor concentração que os demais aminoácidos. Assim sendo, uma dieta baseada exclusivamente nestes animais não seria adequada, por ser sua proteína desbalanceada.

De qualquer forma, a carne de moluscos não era a mais importante fonte de proteínas para os antigos moradores do litoral sul brasileiro: os peixes eram pescados em grande quantidade, como já mostravam as primeiras escavações sistemáticas (Emperaire e Laming 1956), confirmadas por pesquisas recentes. Os moluscos eram também consumidos pelos moradores indígenas do interior, pois, em 1598, o cronista G. Soares de Souza escreve que os moradores do rio São Francisco comem "caracois do tamanho de oito reais... os quais fazem mal aos índios, se comem muito".

\section{Os instrumentos de concha}

As conchas de moluscos fornecem uma matéria-prima abundante em certas regiões e se prestam perfeitamente para a fabricação de instrumentos e adornos. Com efeito, embora os carbonatos de cálcio que as compõem sejam frágeis (dureza 3, na escala de Mohs), seus cristais, revestidos por proteínas, se articulam em estruturas laminares sobrepostas cruzadas cujas interfaces criam um eficiente defletor de pressão, dissipando a aplicação de energia externa. Assim, é possível usar as conchas para elaborar uma grande variedade de instrumentos ativos equivalentes a muitas categorias de instrumentos de pedra. Embora os adornos tenham sido facilmente reconhecidos, particularmente em sepultamentos, muitos instrumentos podem ter passado despercebidos durante as escavações.

As escavações realizadas no sambaqui do Moa poporcionaram 131 artefatos de osso, 660 de pedra e 120 artefatos malacológicos (14\% do total). Considerando que os vestígios líticos registrados eram em grande maioria resíduos de lascamento de 
quartzo de filão sobre bigorna, não parece arriscado supor que, pelo menos neste sambaqui, os instrumentos de concha totalizariam cerca de um terço de todos os instrumentos encontrados pelas escavadoras neste sítio. Talvez a proporção não seja muito diferente em muitos utros.

Basicamente, são disponíveis dois tipos de material conchífero: as conchas de bivalves (abertas e pouco recurvadas) e as de gastrópodes (fechadas e espiraladas). Existem tanto conchas finas e frágeis quanto outras espessas e altamente resistentes como aquelas do Strombus gigas.

\section{Os instrumentos ativos com gume}

São os mais numerosos e possuem geralmente um gume periférico ou aberto no meio da concha. Aqueles da primeira categoria incluem facas, raspadeiras, serras, raspadores côncavos, goivas (que trabalham por pressão linear), furadores, anzóis e serras (atuam por pressão puntiforme - simples ou multipla), lâminas de enxo (percussão linear) e pontas de projétil (percussão puntiforme).

As facas (cuchillos)

Etnograficamente, não faltam os exemplos de utilização de conchas de bivalva como faca. Com elas os índios Kamayura do Alto Xingu descascam a mandioca amarga; os Bororo (Albisetti e Venturelli 1962; Colbacchini 1925) cortam os cabelos com conchas de espécies dos pântanos, que medem até $15 \mathrm{~cm}$ de comprimento.

As conchas mais espessas e duras, tais como as de Lucina/Phacoides, Mactra, Macrocalista e até Ostrea no litoral, ou Diplodon no interior não precisariam ser retocadas. As conchas de mexilhão (Modiolus, Mytilus) e de Pinctata, mais frágeis, seriam utilizadas apenas casualmente e poderiam cortar carne - o que não deixariam vestígios identificáveis para os arqueólogos, pois seus gumes quebrariam-se e se alterariam rapidamente. Contudo, encontramos vestígios de uso (provavelmente em osso ou madeira) em conchas robustas de Lucinidae no sítio do Buracão, onde valvas tanto esquerdas como direitas - de até oito $\mathrm{cm}$ de comprimento tinham a borda afetada por pequenas denticulações contínuas em 2 ou $3 \mathrm{~cm}$. Vários autores assinalam vestígios de utilização em ostras: no sambaqui de Guaraguaçu (Andreatta e Menezes 1975: 153), nos acampamentos do Buracão (Pallestrini 1964) e Armação do Sul (Rohr e Menezes 1969) ou em concha fluvial de Diplodon na Lapa Pequena de Montes Claros (Minas Gerais), onde Bryan (1978) baseia seu diagnóstio em estrias oblíquas. Este último caso nos parece duvidoso, já que verificamos a presença desses riscos em toda a face externa da concha aludida e não preferencialmente na borda supostamente ativa. De fato, a relativa fragilidade dos gumes de concha - não somente em razão de pressões mecânicas nos sedimentos, mas também dos fenômenos de dissolução - torna difícil um estudo traceológico dos instrumentos. Contudo, estudos de M. E. Mansur e N. Buc sugerem que as marcas de corte deixadas em osso por instrumentos de concha posam ser diferenciadas daqueles provocadas por instrumentos líticos. 
Raspadores laterais (raederas)

São instrumentos retocados em concha de bivalva para ter uma borda ativa retilinear ou levemente convexo e um gume mais abrupto que o bordo natural, sendo, portanto, menos cortante, no entanto mais robusto (Figuras. 2a, 2b, 2e). Podem ser tanto usados como facas de gume reforçado para trabalhar matérias mais duras que a carne, ou por pressão transversal, para raspar: escamas de peixe, madeira, etc.

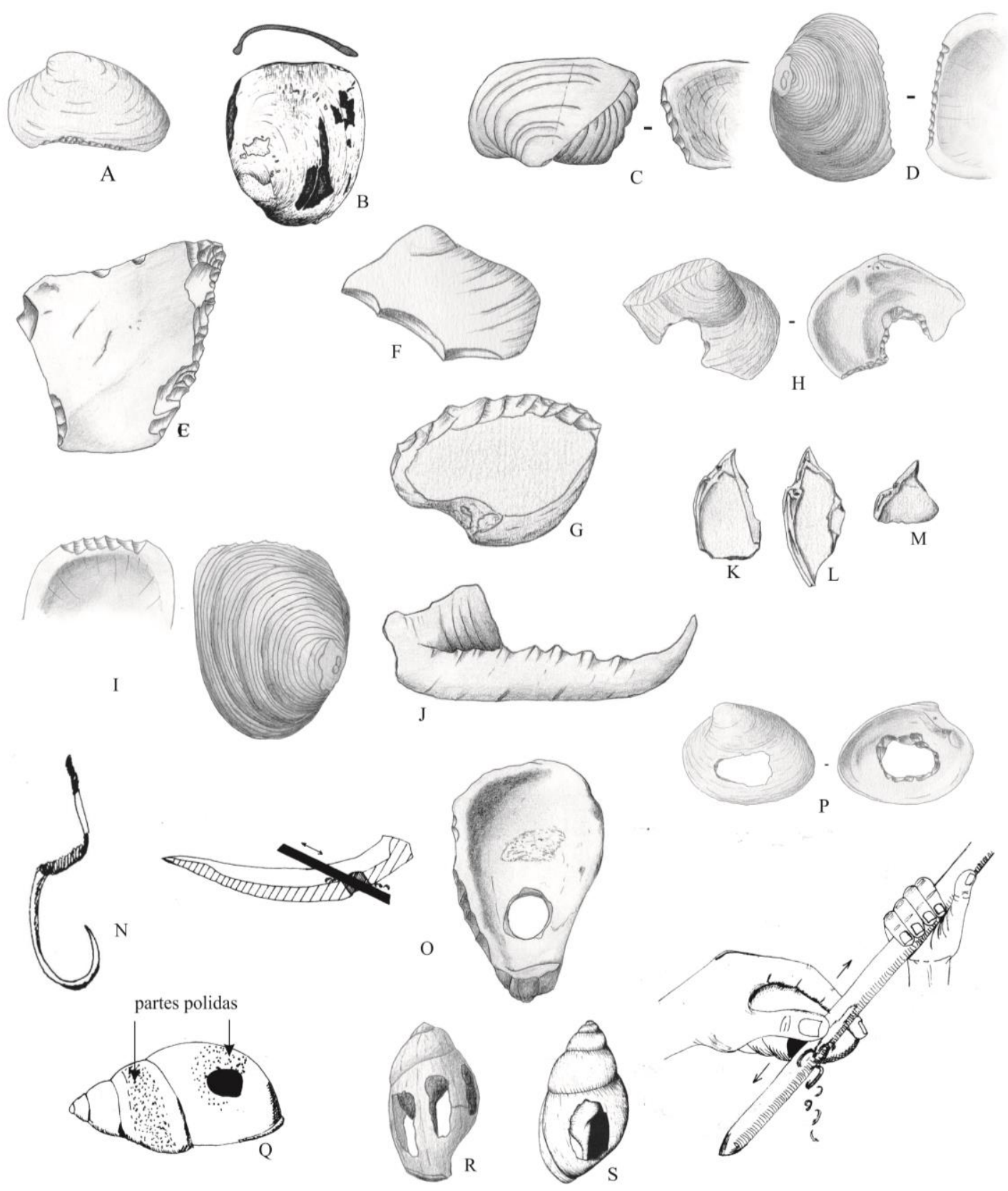

A e B- Facas (A- Acampamento do Corondó, apud Carvalho 1984; B- Abrigo do Boquete, MG, apud Prous 2009); E- raspadeira de concha (Sambaqui do Rio de Janeiro, apud Beltrão 1976); F e G- serra e denticulados (G- Cabeçudas de Itajai, SC, apud Schmitz 1996); H- raspador côncavo (Sambaqui da Caieira II, apud Lima 1991); I- Micro goiva (Lapa Vermelha IV, MG, apud Prous 1992); J. K, L e M- Furadores (Corondó, RJ, apud E. Teixeira de Carvalho 1994); N- anzol (Bororo, apud Prous 1986/1990); O- ostra perfurada (Id. ibid.); P- Concha perfurada de bivalva, descascador? (Sambaqui Caieira II, apud T. Lima 1991); Q- plaina/polidor (Bororo, apud Prous 1986/1990); R e S- plainas (R- Corondó, RJ, apud E. Teixeira de Carvalho 1984; S- Lapa do Aboclo, MG, apud Prous 2009).

Figura 2. Instrumentos de gume. 
Os exemplos típicos são raríssimos: Beltrão (1976) mostra um exemplar de Tivela ventricosa com várias linhas de retoque encontrado por Castro-Faria no sambaqui do Boqueirão (RJ). Kneip identificou, em suas escavações, numerosas peças confeccionadas com Lucina pectinata e Callista maculata no sambaqui Zé Espinho e 110 "raspadores" no sambaqui do Moa (Rio de Janeiro; Silveira 1994). Rauth (1962) teria encontrado "raspadores" de ostra em Saquarema (Paraná). Como não se trata, com certeza, de raspador terminal, a palavra "raspador" deve ser aqui sinônima da nossa raspadeira; no entanto, o autor não especifica se o objeto foi retocado. Em várias publicações, os autores não separam o que seriam peças denticuladas (usadas como serras) de raspadeiras ou de facas com marcas de uso. Inclusive, uma mesma concha particularmente de Lucina - podia ser aproveitada para as diversas funções que exigiam um gume linear. Num setor restrito do sítio ceramista Itararé de Cabeçudas (litoral de Santa Catarina), Rohr registrou uma concentração de onze valvas de Lucina utilizadas e retocadas - quase todas aquelas que foram encontradas na escavação de $38 \mathrm{~m}^{2}$. Isto sugere a existência de um verdadeiro ateliê de trabalho especializado neste “acampamento" litorâneo (Schmitz 1996).

Uma utilização de conchas resistentes como raspadeira (movimento perpendicular ao eixo do gume, à diferença da faca, onde o movimento acompanha o bordo ativo) não implica sempre um retoque preparatório, Assim, conchas usadas desta forma podem não ser identificadas pelo arqueólogo. Tais conchas usadas como raspadeira podem ser observadas entre os oleiros Waura para regularizar a espessura dos potes de cerâmica antes da queima (V. Penteado Coelho, comunicação pessoal).

\section{Serras (sierras)}

São instrumentos de gume serrilhado por retoque em conchas robustas de bivalva (sobretudo Lucina, mas também as menos robustas Macoma, Mactra e Macrocalista) (Figura 2f, 2g). Estes instrumentos foram reconhecidos por Leonardos $(1938,1939)$, no estado de São Paulo, por Emperaire e Laming (1956), nos estados do Paraná (Rauth 1971) e no norte de Santa Catarina, (Prous e Piazza 1977). Seriam muito freqüente na Tradição Itaipu de acampamentos pré-cerâmicos em zona lacustre do estado do Rio, nos quais E. Carvalho (1984) identificou mais de 450 Macrocalista com bordo ativo serrilhado e estrias (de utilização?) ainda visíveis, além de centenas de fragmentos do mesmo tipo de instrumento no sítio do Corondó. Talvez sejam deste tipo os instrumentos de concha que Calderón (1964) encontrou no sambaqui da Pedra Oca, no estado da Bahia.

\section{Raspadores côncavos (escotaduras)}

Apresentam uma parte ativa retocada obliquamente formando uma reentrância, geralmente semicircular (Figura $2 \mathrm{~h}$ ). Como o entalhe costuma penetrar fundo nas valvas, o instrumento tem um formato semelhante a lua crescente. A função desses objetos seria de descascar e regularizar varas cilíndricas de madeira ou de osso. No 
entanto, acreditamos que esta feição possa ocorrer acidentalmente, sem que houvesse intenção de se formar este tipo de gume. Por exemplo, uma ostra com reentrância muito profunda do Ramal (Rauth, 1971) pode decorrer de uma fratura acidental da concha quando se tentava abrir um buraco central. Já não é o caso para gumes côncavos abertos no lábio externo de gastropodos pequenos (Olivancillaria, de $4 \mathrm{~cm}$ de comprimento) em Forte Marechal Luz (Bryan 1977) e Cabeçudas (Schmitz 1996), que foram realizadas de maneira bem controlada e não devem ser confundidas com outras reentrâncias feitas para facilitar a amarração de pingentes em conchas de Bulla ou Terebra. Verdadeiros raspadores côncavos foram feitos sobre conchas de bivalva em vários pontos do litoral de Rio de Janeiro coo mostram as pesquisas do Instituto de Arqueologia Brasileira (Carvalho 1984) e de Lina Kneip (1997), São Paulo e Santa Catarina. Em Piaçaguera e no Sambaqui do Buracão, acompanham sepulturas (Pallestrini 1961). Foi provavelmente um instrumento deste tipo que Simões (1967) achou em sitio cerâmico do Alto Xingu.

\section{Microgoivas (micro gubias)}

São conchas de bivalvas cujo bordo anterior ou posterior foi retocado para formar um gume reto ou levemente côncavo em projeção vertical e côncavo em corte transversal (Figura 2, 2c a I). Encontramos estes instrumentos apenas em dois sítios de Minas Gerais (Lapa Vermelha IV e Lapa Pequena), onde foram aproveitadas conchas de Diplodon de 6-8 cm de comprimento; os retoques são direitos (ou seja, os golpes aplicados desde a face externa, provocando saída de lascas na face interna).

\section{Furadores (perforadores)}

São artefatos que apresentam um setor retocado pontudo (Figura $2 \mathrm{j}$ a $2 \mathrm{~m}$ ). Durante a utilização, a pressão é geralmente aplicada de maneira rotativa, o que pode deixar estrias de uso oblíquas. O primeiro exemplo inquestionável assinalado é um fragmento de lábio de um grande gastrópodo marítimo não identificado, apontado em uma extremidade, gasta pelo uso. Achado em Conquista (SC), tem 17 cm de comprimento e uma larga parte de preensão (Tiburtius 1966). Mais recentemente, Carvalho (1984) descreveu 136 furadores sobre valvas dorsais de Macrocalista maculata, cujas extremidades foram aguçadas pela retirada de parte das regiões anterior e posterior (sítio Corondó). Souza e Souza (1981/82) assinalam furadores feitos com columelas de gastropodos no sambaqui do Rio Pedrinhas (RJ). Rauth (1971) identifica também como perfuradores dois artefatos de $6 \mathrm{~cm}$ de comprimento que, pela ilustração, parecem feitos a partir do lábio externo de Strophocheilideae. 
Anzóis (anzuelos)

Até o início do século $\mathrm{XX}$, os indios Bororó separavam da espira corporal o lábio reforçado dos Megalobulimus para obterem anzois de ótima qualidade (Albisetti e Venturelli 1962) (Figura 2n). Encontramos lábios isolados semelhantes em abrigos do estado de Minas Gerais (Lapa Vermelha IV, Boquete), contudo sem indicio de terem sido retocados ou utilizados.

Pontas

Poucos autores mencionam pontas de concha. Rauth $(1967,1969,1971,1974)$ e Krone (1914) teriam encontrados este tipo de artefato feito com valva de Ostrea em sambaquis dos estados do Paraná e de São Paulo. Contudo, são simples peças pontudas, uma delas com um "esboço de pedunculo". Na falta de uma descrição detalhada, não se sabe se há realmente retoques, e devemos esperar novos estudos para aceitar a existência desta categoria tipológica; as peças mencionadas poderiam também ser fragmentos naturais (a casca de muitas ostras desmancha-se, deixando lascas agudas), ou furadores. Já em domínio amazônico, Bandeira (2008) encontrou no sambaqui do Bacanga - estado do Maranhão - uma peça inédita com pedúnculo e aletas que parece mais convincente. Foi feita a partir de uma placa fina de valva de Ostrea. Os instrumentos perfurados incluem tanto bivalvas quanto gastrópodos.

Ostras perfuradas: possíveis enxós (azuela)

Acreditamos que conchas robustas como as valvas de grandes ostras possam ter sido utilizadas como enxó (Figura 2o). Estudamos alguns exemplares tirados de Tridacna nas coleções oceânicas (Nova Guinea) do Museu do Homem de Paris, enquanto Cruxent e Rouse (1961) fornecem exemplos venezuelanos. Nestes casos, a valva foi inteiramente formatada, tendo perdido a forma original. Nada semelhante foi observado no Brasil; contudo, algumas conchas de ostra se prestam a serem utilizadas sem grandes modificações, ou com uma simples amelioração da parte a ser encabada. Por isto nos interessamos às numerosas "ostras com perfuração central", No norte de Santa Catarina, muitas conchas perfuradas têm o orifício de 1 até mais de $2 \mathrm{~cm}$ de diâmetro, enquanto a valva pode ultrapassar $25 \mathrm{~cm}$ de comprimento. Observamos 29 exemplares provenientes do sambaqui Morro do Ouro, cuja perfuração tinha sido realizada por percussão a partir das duas faces externas da concha, enquanto as peças da Conquista descritas por Tiburtius apresentariam marcas de percussão a patir exclusivamente da faxe interna.

Parte desses artefatos tem o furo localizado perto da charneira. Considerando-se que as valvas têm geralmente uma forma subtriangular, o furo encontra-se num ângulo oposto a borda menor, que poderia ter formado um gume. Assim acreditamos que a abertura poderia ter sido utilizada para encabar o objeto; este poderia ter sido usado para trabalhar a terra ou abrir ou couro de cetáceos. 
Conchas perfuradas de bivalvas: descascadores

Não são apenas conchas Ostrae que apresentam abertura interna de origem antrópica; também exemplares de Lucina, de Mactra e de Macrocalista evidenciam aberturas centrais grandes demais para serem furos de suspensão (Figura 2p). A concha de Lucina é particularmente resistente; mede até $7 \mathrm{~cm}$ de comprimento e sua espessura pode ultrapassar $2 \mathrm{~mm}$.

Vimos no parágrafo anterior que a interpretação pela qual as ostras perfuradas seriam enxós não pôde ser demonstrada. A outra possibilidade é que a parte ativa dos instrumentos seja a borda interna do orifício. Neste caso, assim como para as conchas resistentes de outras espécies, seria possível usá-las como calibrador para obter cilindros finos de matérias macias (madeira). Pequenos "retoques" podem ser observados no fio interno de conchas menores (Lucina, de Mactra e de Macrocalista), sem que possamos afirmar se são devidas à preparação ou a utilização, pois não chegamos a realizar experimentações para avaliar as possibilidades de identificação.

Em compensação, nossas experiências em ostras mostram que, a partir de $2,5 \mathrm{~cm}$ de diâmetro, os gumes internos se prestam perfeitamente às operações de descorticamento de varas de até $2 \mathrm{~cm}$ - melhor inclusive que um raspador côncavo podendo o artesão utilizar ao mesmo tempo dois gumes opostos. A pressão provocada pelo movimento da madeira na borda do furo provoca um lascamento que reaviva sempre o gume da concha. Tal utilização convem, particularmente, a peças com perfuração bem central.

Tiburtius (1960) descreve os exemplares perfurados de Lucina que encontrou em Santa Catarina, separando-os em duas categorias. A primeira reúne as conchas com uma perfuração aproximadamente central e circular, com diâmetro entre 15 e $20 \mathrm{~mm}$, obtida por percussão inversa. Sempre foram achadas isoladamente e nunca na proximidade de sepultamentos. A segunda apresenta um orifício central muito maior, desenvolvido a partir de um furo do tipo anterior. As bordas seguem as estrias de crescimento da concha, da qual acaba sobrando apenas o anel periférico. Tiburtius compara o resultado final a brincos, mas não há nenhum sinal de regularização, como seria um polimento. Esta segunda categoria se refere a peças encontradas associadas entre si (até 24 juntas), de tal maneira que poderiam ser enfiadas numa corda. Nenhum desses tipos parece adorno, já que o sistema de suspensão difere muito daquele que foi normalmente utilizado em elementos de colar dos mesmos sítios. Poderiam ser descascadores em fase adiantada de desgaste.

No litoral de São Paulo, as conchas de Mactra e Macrocalista apresentam perfurações semelhantes em vários acampamentos litorâneos, onde acompanhavam por vezes os sepultamentos (sítio do Tenório). As perfurações medem entre 16×25 $\mathrm{mm}$ e $32 \times 27 \mathrm{~mm}$, sendo de dimensões intermediárias entre as dos dois grupos de 
Tiburtius. A forma do orifício nem sempre acompanha à da valva e o artefato nunca chega a adquirir a aparência de brinco. Segundo A. Kern (1989), conchas de Amiantis purpurata tembém teriam sido perfuradas desta maneira no litoral norte do Rio Grande do Sul.

Gastrópodos com grandes perfurações: plainas (cepillas)

Os zoólogos Biocca, Hoge e Schreiber (1947) a reconhecerem a existência de instrumentos feitos com as conchas perfuradas de grandes gastropodos terrestres da família Strophocheilideae (subfamília Megalobuliminae) nos sambaquis do estado de São Paulo (Figura 2q-2s). Contudo, durante muito tempo, os arqueólogos atribuíram estes orifícios à pressão do sedimento (Guidon 1964), à dissolução das conchas (Duarte 1968) ou à ação humana para extrair a lesma da concha (Schorr 1976).

Encontramos centenas de exemplares semelhantes em nossas pequisas no estado de Minas Gerais. Por exemplo, estudamos milhares de conchas não perfuradas - inteiras, fragmentadas e/ou erodidas - provenientes das escavações da Lapa Vermelha IV (na região de Lagoa Santa), das Lapas do Dragão, do Malhador e do Boquete (no norte do estado de Minas Gerais); no meio deste material, encontramos cerca de 60 peças somente na Lapa Vermelha, dezenas de peças inteiras e de fragmentos nos outros três abrigos, assim como uma centena de peças perfuradas provenientes de uma dúzia de outros sítios arqueológicos. Nossas observações nos levaram ao mesmo diagnóstico que Biocca, Hoge e Schreiber. Com efeito, a dissolução natural das conchas em sedimentos ácidos após morte das lesmas, assim como a raspagem por moluscos vivos que reciclam os carbonatos para formar as próprias conchas (Santos 1955) produzem feições totalmente diferentes, reduzindo a espessura desta proteção e transformando finalmente sua superfície em uma espécie de renda. O peso dos sedimentos e as quedas de pedra causam fraturas ou quebras estreladas também bem distintas do que se observa nos exemplares com perfurações elípticas ou circulares. Por outro lado, tentar tirar a lesma da concha furando a parede é totalmente inútil: basta expor o animal poucos minutos ao calor perto de brasas para que ele solte sua baba, desidrata e morra, soltando-se da espira e preservando a concha. Sobretudo, é inconveniente: o operador acaba quebrando a concha toda e fica com a mão cheia de um muco pegajoso e nojento, quase impossível de tirar.

Finalmente, as diversas experimentações que fizemos a partir de conchas frescas nos permitiram reproduzir exatamente as características das aberturas observadas nas conchas. Bastava percutir de forma controlada as espiras com um pequeno batedor de extremidade arredondada (preferencialmente um seixo alongado).

A etnografia nos trouxe a chave para identificar o uso (ou pelo menos um deles) daqueles instrumentos. Os índios Guayakí do Paraguai, os Bororo do Mato Grosso (Albisetti e Venturelli 1962) e os Xikrin do Pará preparam a madeira dos seus arcos 
descascando-a com o gume interno criado pela abertura dos orifícios, e polindo-a (o que fecha as fibras da madeira, evitando que a mão se machuque com fiapos) com as partes intactas da espira. Os poucos exemplares etnográficos que pudemos ver no acervo do Museu de Arqueologia e Etnologia da Universidade de São Paulo apresentam um único furo, mas uma ilustração de von den Steinen (1884) mostra um instrumento com quatro furos pouco alongados, descrevendo a seguir sua utilização. Nossas experimentações evidenciaram o excelente desempenho destes instrumentos como descascadores e plainas. Em nosso filme "Arqueologia no Brasil" (Prous/Embrafilme 1977) demostramos a eficiência deste instrumento. Finalmente, encontramos no sítio de Brejinho IV (perto de Montalvânia) uma concha (não perfurada) cheia de fiapos compactados absolutamente semelhantes àqueles que tínhamos obtido ao descascar galhos. Nota-se que estes fiapos, uma vez secos, fornecem um excelente material para acender fogo.

A totalidade das dezenas de artefatos no norte de Minas (região de Januária e Montalvânia) tem uma única perfuração, enquanto 50 \% dos artefatos da região de Lagoa Santa ou do litoral meridional apresenta entre 2 e 5 aberturas. Em ambos os casos, as conchas têm entre 1,2 e 2 mm de espessura, não havendo relação direta entre o tamanho da concha (que varia entre 9 e $12 \mathrm{~cm}$ ) e o número de furos praticados. Os artefatos com furo único têm seu orifício normalmente localizado na primeira volta, à direita, o que permite uma boa preensão para uso como plaina; a única exceção, com perfuração da primeira volta, mas no lado esquerdo, poderia ser mais adaptada à utilização por um canhoto.

Os orifícios, circulares ou elípticos, são feitos por percussão a partir de uma zona próxima à sutura, porém sem chegar a ela - o que permite conservar um gume posterior. $\mathrm{O}$ trabalho progride em seguida para frente da concha, acompanhando uma ou várias estrias de crescimento. O resultado é, nos abrigos de Minas Gerais, uma abertura elíptica sub-retangular, alongada no sentido anter-posterior, paralela ou pouco oblíqua em relação ao eixo columelar e com dois bordos ativos opostos côncavos nos lados menores. A relação L/C (largura-comprimento) do orifício fica geralmente entre $4 / 5$ e $1 / 2$. Por vezes, o furo primitivo, muito paralelo ao eixo do suporte, foi retocado para permitir um uso oblíquo. A largura do orifício vai de 11 a $22 \mathrm{~mm}$ (com raras exceções de 9 até $30 \mathrm{~mm}$ ) e permite descascar ou raspar varas de 3 a $5 \mathrm{~cm}$ de diâmetro.

No litoral parece haver uma tendência à fabricação de orifícios mais circulares que no interior, com uma relação $1 / C$ avizinhando-se de 1/1. Os artefatos com várias perfurações mostram mais regularidade ainda. A primeira perfuração, ainda na primeira volta a direita, costuma ser maior que as outras (e que os furos únicos do tipo anterior), chegando em vários casos a mais de $4 \mathrm{~cm}$ de comprimento, sem que a largura seja maior. A relação L/C varia, portanto, entre 3/5 e 1/3, chegando a $1 / 4$ no litoral (Mar Casado). A partir da terceira perfuração, as dimensões são menores, pela própria falta de espaço na espira menor. Com efeito, em Minas Gerais, as perfurações são 
bastantes distantes uma da outra e nunca ultrapassam o número de cinco; a disposição é sempre na mesma ordem: primeira volta direita; primeira esquerda (eventualmente: primeira ventral); segunda direita; segunda esquerda. Quando há dois orifícios abertos na primeira volta, a concha torna-se frágil e há exemplos de ruptura da parede entre dois furos vizinhos. Acreditamos assim que algumas das peças com aberturas longas, próximas umas das outras poderiam ter sido destinados a funções que não implicariam tanto esforço mecânico quanto trabalho da madeira.

\section{Instrumentos "passivos" sem gume: polidores, recipientes e espátulas}

\section{Polidores e calibradores}

Já reportamos informações etnográficas informando que as conchas de Strophocheilideae são utilizadas para polir madeira e cerâmica (Albisetti e Venturelli 1962). Encontramos na coleção Bororo da USP proveniente da aldeia de São Lourenço uma concha perfurada como plaina, cuja casca entre os orifícios era desgastada até o ponto que os relevos das estrias de crescimento desapareceram, certamente após longa utilização como polidor. Até agora, nenhum artefato conquiológico com marcas resultantes deste tipo de uso parece ter sido identificado em sitio arqueológico.

Membros do Instituto de Arqueologia Brasileira mostraram, na oportunidade de uma filmagem televiziva, conchas de gastropodo marinho cuja espessa parede mostrava profundos sulcos na face dorsal - alguns chegavando a furar a parede. Tratar-se-ia, possivelmente, de calibradores. No sitio da Malhada, são conchas de bivalvas que foram aproveitadas para este fim (Dias 1980). Segundo informação verbal de Josaphat Penna, os prisioneiros encarcerados no presídio de Neves (Minas Gerais) esfregariam com uma concha de Strophocheilideae a palha de milho com a qual enrolam seus cigarros.

\section{Recipientes}

A própria morfologia das conchas as predispõe a servir de recipiente: aberto (conchas de bivalvas) ou fechados (conchas de gatrópodos) (Figura 3a a 3d). Como é raro que esta utilização deixe vestígios, o arqueólogo tem as maiores dificuldades para interpretar os achados neste sentido, a não ser pelo contexto em estruturas domésticas.

\section{Depósitos rituais}

Perto de Joinville (Santa Catarina) Tiburtius e Bigarella (1960) relatam o achado de uma valva de ostra que teria sido aproveitada para conservar vários ossos de pássaro, bem como uma escultura de osso representando um volatil (o zoomorfo $\mathrm{n}^{\circ} 205$ do nosso catálogo: Prous 1974). Neste caso, tratar-se-ia de um depósito possivelmente ritual. 

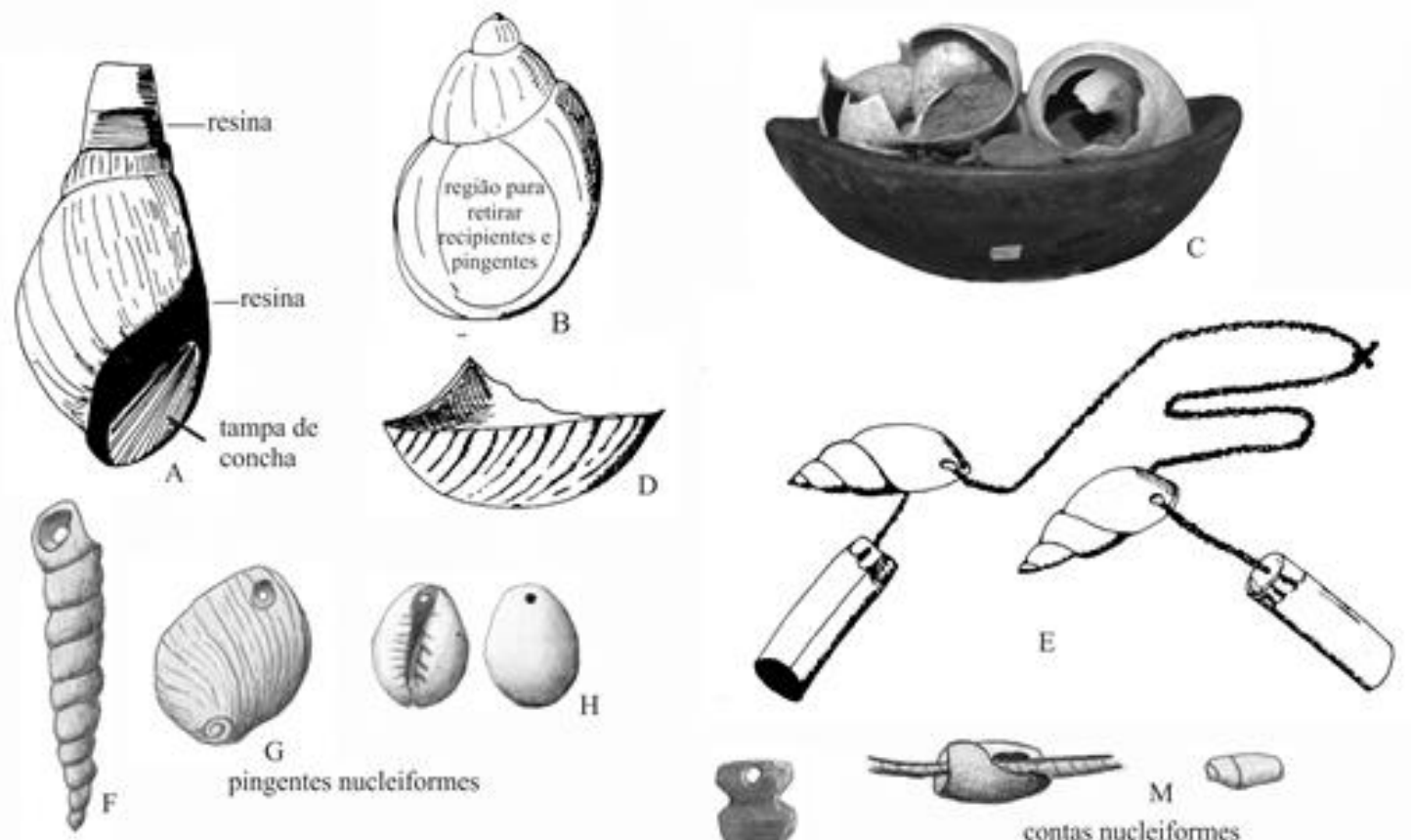

pingentes nucleiformes
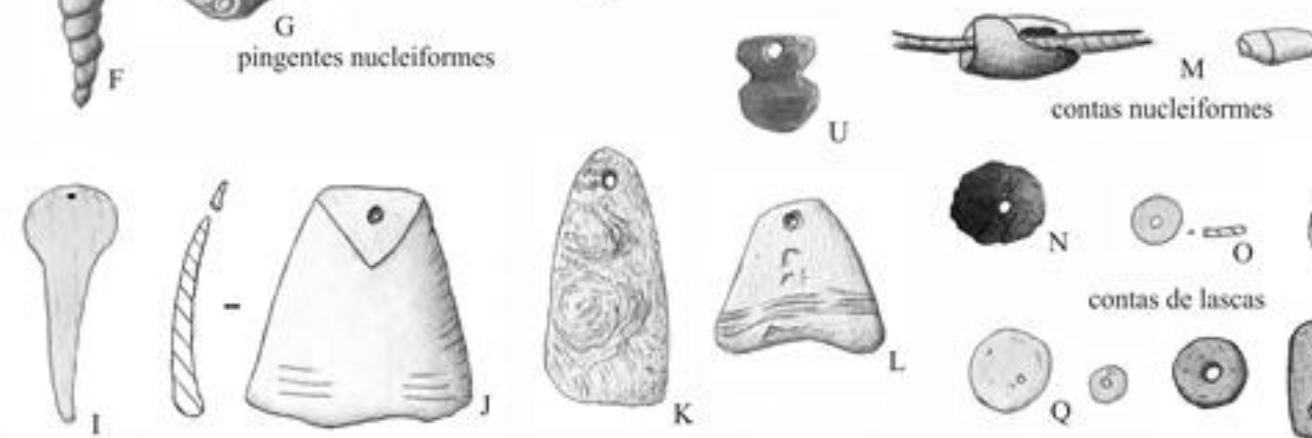

contas de lascas

pingentes de lascas
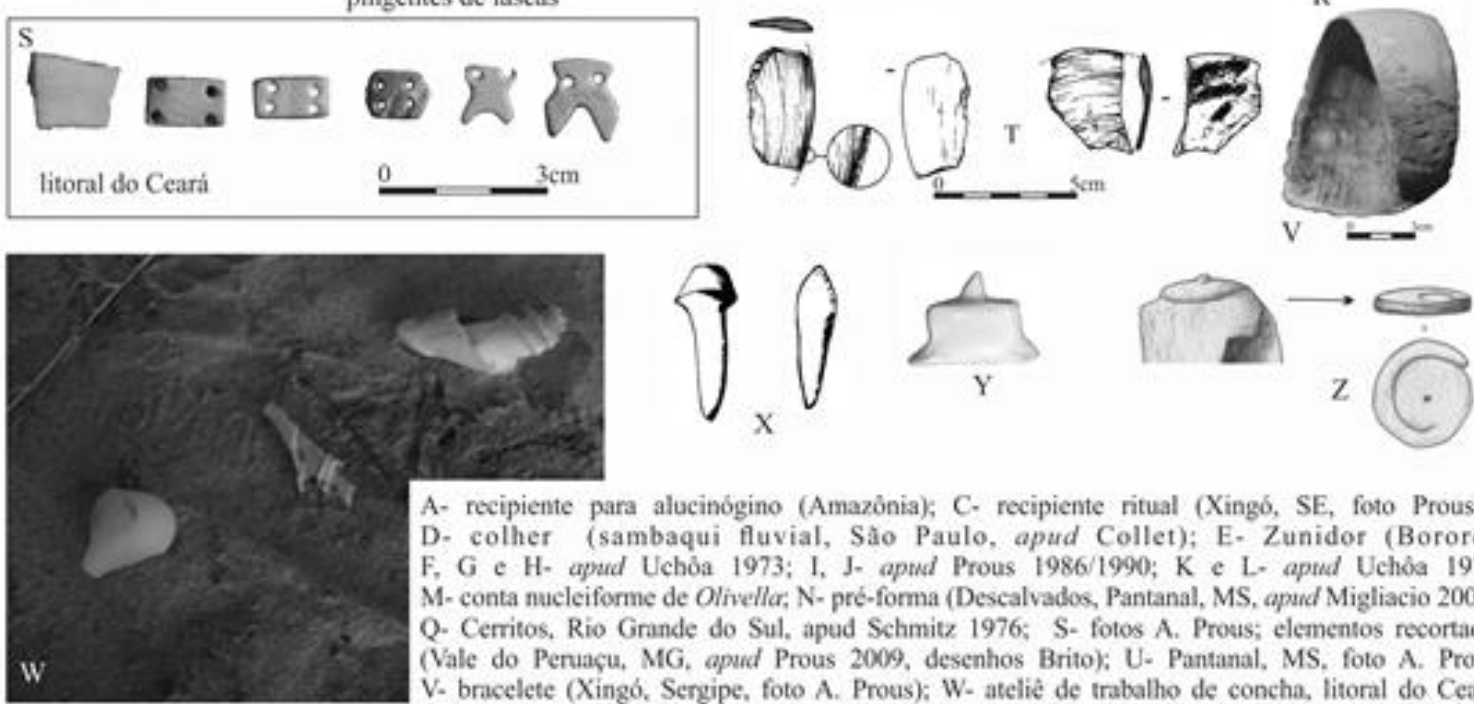

A- recipiente para alucinógino (Amazônia); C- recipiente nitual (Xingó, SE, foto Prous) : D. colher (sambaqui fluvial, São Paulo, apud Collet); E- Zunidor (Bororo): F, G e H- apud Uchổa 1973; I, J- apud Prous 1986/1990; K e L- appd Uchỏa 1973; M- conta nucleiforme de Olivella, N-pré-forma (Descalvados, Pantanal, MS, apud Migliacio 2006); Q- Cerritos, Rio Grande do Sul, apud Schmitz 1976; S- fotos A. Prous; elementos recortados (Vale do Penuaçu, MG, apud Prous 2009, desenhos Brito); U- Pantanal, MS, foto A. Prous: V- bracelete (Xingó, Sergipe, foto A. Prous); W- ateliê de trabalho de concha, litoral do Ceará; $X, Y$ e Z- columelas trabalhadas (X-tembeta??, Santa Catarina: $Y$ - litoral do Ceara).

Figura 3. Recipientes e adornos.

Godês (godete)

Foram encontradas valvas de lamelibrânquios ainda cheias de pigmento formando uma pasta compacta. Uma delas, de Diplodon, com $7 \mathrm{~cm}$ de comprimento, consta de uma antiga coleção de peças provenientes da região de Lagoa Santa. No sambaqui "B" 
de Guaraguaçu (estado do Paraná) 21 conchas de Ostrea apresentavam esta particularidade (Andreatta e Menezes 1975).

No abrigo da Furna do Estrago (estado de Pernambuco), blocos de pigmentos minerais e conchas de Strophocheilidae cheias de pó colorido foram encontrados perto do crânio e do púbis de vários adultos (Dias Lima, 1999). A.Laming-Emperaire (comunicação pessoal) nos informou que godês de concha para guardar pasta de urucum são também conservados nas coleções etnográficas do Museu Nacional do Rio de Janeiro.

Conchas de gastrópodos foram preferidas para conter sólidos não pastosos.

Encontramos no pré-cerâmico tardio da região de Montalvânia (Brejões IV, Dragão) conchas de Magalobulimus cheias de casca seca, em tiras finas, como costumam sair quando se raspa a madeira com as plainas, descritas anteriormente. Estes recipientes não eram perfurados e a casca estava comprimida para encher completamente o espaço interno. Acreditamos que fossem reservas de combustível para acender fogo, facilmente transportados durante expedições.

Os mesmos grandes caramujos são utilizados na Amazônia ocidental e em outras regiões sul-americanas para guardar pó alucinógeno (Melatti 1986; Ribeiro 1988).

Recipientes para líquidos teriam que ser grandes e, no litoral, conchas de Ostrea seriam as mais adequadas para tanto. No sítio da Base Aérea perto de Florianópolis, Rohr (1959: 207) observou ostras que mediam até 35 x $13 \mathrm{~cm}$; mesmo assim, raramente podem conter mais que o equivalente de meio copo. Bryan (1977) descreve uma estrutura culinária complexa no sambaqui de Forte Marechal Luz, dentro da quais grandes ostras podem ser interpretadas como recipientes. Lima e Silva (1984) interpretam da mesma forma as 47 valvas de Ostrea encontradas na Ilha de Santana (RJ) onde as ostras não existem naturalmente, nem aparecem no refugo alimentar - rico em outras espécies de bivalvas. No entanto, tais interpretações somente podem ser feitas quando se consideram as relações entre os vestígios arqueológicos a partir de uma planta de vestígios levantada em escavação por níveis naturais e não quando se pratica uma simples coleta, mesmo com ajuda de estratigrafia arbitrárias - como costuma ocorrer nas escavações praticadas no Brasil. Indices discretos como a disposição de conchas no meio de um sedimento heterogêneo podem enriquecer consideravelmente nossos conhecimentos paleo-etnográficos.

Até poucos decênios atrás, os seringueiros da Amazônia utilizavam a concha de Ampullaria gigas - um grande gastropodo - para coletar o látex que corria dos troncos da Hevea. 
Colheres (cucharas)

Era de se esperar que grandes valvas fossem também utilizadas como colheres, até sem transformações. De fato, os Bororó utilizavam como colher a mesma concha com a qual cortam os seus cabelos, e o instrumento tem, em sua língua, o mesmo nome (Atu) que o animal (Colbacchini 1935; Albisetti e Venturelli 1962).

Espátulas?

Em suas escavações nos sambaquis do Moa (litoral dos lagos, Rio de Janeiro), Kneip encontrou dois artefatos que identifica com espátulas (Guimarães 2007); infelizmente, não encontramos ilustração nem descrição precisa destas peças.

\section{Outras utilizações}

\section{Instrumentos musicais}

É bem conhecida a utilização de grandes conchas como tromba; contudo não se tem registro desta prática no Brasil. Alguns achados arqueológicos foram interpretados como instrumentos musicais (Figura 3e). No Sambaqui de Maratuá (estado de São Paulo) foram encontradas duas valvas ainda articuladas de Lucina, no interior das quais outras duas, menores, continham vários ossinhos - inclusive uma falange humana. Emperaire e Laming (1956: 53) acharam que o objeto poderia funcionar como um chocalho; contudo, também poderia ser um depósito ritual ou parte de um estojo xamanístico. Várias das pequenas conchas de gastrópodes perfuradas que mencionaremos mais adiante como adornos poderiam ter sido elementos de chocalhos fixados em tornozeleiras. A. Laming-Emperaire (comunicação pessoal) observou três objetos etnográficos no Museu Nacional; transcrevemos o seu texto manuscrito, apenas traduzindo: "extremidades pontudas de gastropodos (os mesmos encontrados em Lapa Vermelha)". Acreditamos que A. Emperaire estivesse se referindo à conchas de Naesiotus; continua: "Base cortada, extremidade perfurada, enfiadas em série na extremidade da corda, que tem algo como $5 \mathrm{~cm}$. Há dois pompons nestes chocalhos, com 6 conchas cada um. A base recortada de cada uma é muito estragada".

Descreve também outro chocalho, formado pela espira de várias conchas maiores, cuja primeira volta e cujo ápice tinham sido retirados. As perfurações apicais eram presas no cordão por resina. Dentes e penas completam o instrumento. Uma terceira peça (nQ 3194) é feita a partir de um Strophocheilideae com três perfurações ovais na primeira volta, o ápice retirado e um furinho nas imediaçces do bordo anterior. Assim sendo, imaginamos que a columela tinha sido retirada, para enfiar um cabo. O objeto era ornado com penas e considerado privativo dos pagés. 
Em 1973, Lehel de Sillimon nos informou que os índios Bororo utilizariam conchas de Strophocheilideae como zunidor. Com a morte deste pesquisador, perdemos a possibilidade de receber maiores esclarecimentos, pois a enciclopédia Bororo não conhece o fato, nem tampouco, o Pe. Venturelli a quem solicitamos informações. Encontramos, porém, no Museu de Antropologia da USP duas conchas fixadas a duas cordas unidas, coletadas em 1937 entre os Bororo e que poderia ter composto um idiofono. A ficha museológica que acompanha o objeto (denominado Bukigo-Botaro) diz o seguinte: "Serve para as comunicações dentro do aldeiamento e feito com tabóca, sendo o fio de ligação feito de fio de tucum. O sinal é dado com o ruído do caramujo ao esticar-se a corda".

Tratar-se-ia, portanto, de uma espécie de zunidor de uso cotidiano, à diferença daqueles de madeira (em forma de peixes), cuja visão era proibida a parte da sociedade. No entanto, tivemos alguma dificuldade para interpretar o texto e entender o funcionamento. Com efeito, o texto se refere a uma concha somente, com uma caixa de ressonância. Fizemos uma experiência com uma concha algo maior que a da peça museológica e conseguimos apenas um ruído razoável, certamente incapaz de ser ouvido em toda uma aldeia. Houve apenas uma pequena melhoria com a utilização de conchas perfuradas (seria esta a razão das grandes perfurações observadas em Megalobulimus do sítio do Buracão?). Ora, o instrumento etnográfico conservado no Museu da USP tem duas conchas, circulando ao longo da corda que liga duas caixas. Não sabemos se isto implica num outro sistema de manipulação, ou se o etnógrafo teria conseguindo dois instrumentos completos e os teria guardado juntos, amarrando as respectivas cordas.

Um fato estranho é que, na Lapa Vermelha, onde havia milhares de grandes Strophocheilideae (Megalobulimus) - mortos de morte natural, queimados em fogueiras ou transformados em instrumentos - encontramos somente dois exemplares de um gênero bem menor (Bulimulus, $7 \mathrm{~cm}$ ), absolutamente semelhante às conchas do Bukigo-Botaro, com o mesmo pequeno furo alongado e irregular nas imediações do lábio externo, a direita da primeira volta. Esses dois exemplares estavam, curiosamente juntos, como o estavam os exemplares do instrumento Bororo. No acampamento litorâneo do Tenório, vimos uma peça idêntica de $5 \mathrm{~cm}$, com furo de $6 \mathrm{~mm}$ de diâmetro. Talvez estes objetos compusessem artefatos semelhantes ao instrumento Bororo.

\section{Antiplástico de concha}

Os sambaquis de tradição Mina dos estados do Pará e do Maranhão (litoral amazônico) tem uma cultura material muito diferente daquela do litoral brasileiro meridional, embora tenham a mesma antiguidade. Uma das suas peculiaridades é a presença de uma cerâmica simples - a mais antiga do país. Trata-se da única tradição ceramista que utilizou conchas moidas como antiplástico. Segundo vários autores como Greber (1938), esta matéria, facilmente obtida no ambiente local, não é muito adequada para esta função - o que pudemos verificar experimentalmente. 
Isto explicaria que tenha sido substituída por caripé (cinzas de cascas de árvore ricas em sílica), cauixi (epículas de espongiários) ou caco moído nas tradições ceramistas posteriores.

\section{Uso medicinal}

É provável que os indígenas soubessem que a baba de vários gastropodos terrestres facilita a cicatrização e ajuda também a regenerar a pele afetada por queimaduras. Isto, porque é muito rica em proteínas, polissacarídeos (que estimulam a formação de colágeno) e elastina. Por isto, os atuais caiçaras (moradores tradicionais do litoral de Cananeia), herdeiros de muitas tradições indígenas, costumam passar o animal vivo sobre feridas abertas, para facilitar a cicatrização. Isto poderia ser a razão da presença de conchas de Strophocheilideae na mão de alguns esqueletos, em sepultamentos do litoral brasileiro e de abrigos do nordeste do país.

\section{Os adornos de concha e elementos de objetos compositos}

Desde a pré-história, conchas foram usadas como adornos, pelo meno na Africa desde o Paleolitico Médio (d'Errico e alii, 2009) e na Europa desde pelo menos o Paléolítico Superior inicial. Trata-se de um fenômeno universal, que se expressa também na pré-história brasileira.

Conchas de tamanho modesto que apresentam um trabalho para facilitar a suspensão são geralmente identificados como elementos que comporiam colares. Os adornos podem usar a concha inteira (adorno "nucleiforme"), apenas preparando a suspensão - furo, reentrâncias e/ou sulco. Ou podem, ainda, ser feitos com uma parte recortada (lasca) do suporte original, que tanto pode ser destinada a ser suspensa a um cordão quanto a ser costurada (neste caso, precisa ser furada) ou colada sobre um suporte vegetal.

Os adornos podem ser divididos em cinco categorias: pingentes, contas tubulares, contas discoidais, adornos labiais (tembetâ) e elementos recortados não suspensos.

Os pingentes são elementos de forma alongada, com sistema de suspensão excêntrico - ou seja, situado no terço externo da peça, enquanto as contas são peças cujo sistema de fixação encontra-se na parte central do volume.

Os pingentes nucleiformes são quase exclusivamente feitos de gastropodos de concha alongada não modificada (Figura 3f a 31, 3u). São, sobretudo, conchas pontudas de Terebra flammea, que podem medir mais de $12 \mathrm{~cm}$ de comprimento; são difíceis de serem encontradas nas praias, pois vivem em grandes profundidades. É, portanto, significativa, a quantidade de exemplares registrada desde os sítios do estado de São Paulo (Maratuá, Mar Casado) até o Paraná (Guaratuba) e os sambaquis de Joinville (Conquista IX): esta concha devia ter um grande valor simbólico. Em Conquista, quatro 
dos cinco exemplares de T. flammea não tinham sido perfurados, mas coloridos de vermelho (Tiburtius 1966). A suspensão era geralmente assegurada por um orifício lascado na parte externa da primeira volta, perto do lábio externo. O sistema foi completado em Maratuá por uma reentrância lascada na parte direita do lábio extremamente resistente. Em Mar Casado algumas Terebrae não são perfuradas e uma delas mostra evidências de um lascamento deste tipo. No sambaqui fluvial do Januário (São Paulo - Collet e Guimarães 1977), um mesogastrópodo perfurado acompanhava um sepultamento. Em dois sítios de São Paulo (Tenório e Maratuá), numerosos exemplares de Cypreae cujo comprimento varia de 20 a 33mm foram perfuradas por percussão inversa (que chegou em um exemplar a provocar rachamento em estrela) perto de uma das extremidades. O orifício é de forma geralmente retangular, com o lado maior perpendicular ao eixo morfológico da concha. Cypreae foram também aproveitadas como elementos de colar no sítio Corondó (RJ). Encontram-se no Museu de Lapinha (Perto de Lagoa Santa) dois pingentes compridos, com uma perfuração, feitos a partir da columeIa de grandes gastrópodes. Ambos são certamente de proveniência local. Conhecemos duas ocorrências de bivalvas aproveitados como pingentes. O primeiro caso é, inclusive, de interpretação difícil: na Base Aérea da ilha de Santa Catarina, Rohr encontrou três peças, das quais duas quebradas, com um ou vários furos periféricos. A peça maior tem um furo quase central além dos três periféricos visíveis na fotografia (Rohr 1959). O outro é de urna valva de Aequipecten, perfurada na proximidade do umbo, encontrada no sambaqui do Boqueirão (RJ) por Castro Faria (Beltrão 1976). Outros Aequipecten, não perfurados, foram encontrados em sepultamento no Buracão (Pallestrini 1964), acompanhado o morto para o Além, como mais tarde iriam acompanhar os Cristãos do Velho Mundo para Compostela.

Os pingentes sobre lascas são mais comuns que os nucleiformes. O cronista A. Thevet (1558) menciona pingentes feitos com columela de gastrópodo usado pelo chefe Tupinamba Quoniambebe. Há raros exemplares recortados em ostras nos sítios paranaenses do Godo e do Macedo (Rauth 1969; Hurt e Blasi 1960) assim como nos de Boguassu, Vila Nova 11 e Maratua no estado de São Paulo (Laming e Emperaire 1956; Krone 1908; Duarte 1968). A quase totalidade dos pingentes sobre lasca, contudo, foi feita a partir da primeira volta de grandes gastropodos, da qual se retirava lascas entre 4 até $11 \mathrm{~cm}$ de comprimento. No litoral, são conchas de Strombus goliath, Cyprea, Cymbiola e Strophocheilideae. Essa última família era também disponível longe do litoral. Nas costas paranaense e paulista, o formato mais comum dos ingentes é trapezoidal, com um só furo de suspensão no lado menor. As peças grandes $(11,3 \times 7 \mathrm{~cm}$ no Buracão) são feitas em paredes muito resistentes, com mais de $2 \mathrm{~mm}$ de espessura. Pudemos verificar que os pingentes deste sítio foram utilizados isoladamente e não com outros elementos de colar, porque o desgaste provocado pelo cordão próximo ao furo era um único micro sulco dirigido verticalmente. As perfurações, tanto no Buracão como no Tenório, têm forma unicônica, sendo realizadas a partir da fase externa (dimensões da ordem de $7 \mathrm{~mm}$ face externa, $5 \mathrm{~mm}$ na face interna) ou bicônica (7 mm $7 \mathrm{~mm}$ ) dissimétrica. Tais perfurações eram praticadas na parte superior depois do objeto ter sido adelgaçada por um polimento de superfície, cujo resultado é uma faceta 
triângulasr plana no meio do qual aparece o furo. Às vezes, este era feito muito próximo à borda superior e a peça quebrava-se transversalmente nessa altura (Buracão). Eventualmente, outro furo era feito mais baixo (Tenório) para não correr o risco de estragar a lasca, cuja retirada do molusco e posterior polimento periférico tinham necessitado um longo trabalho. Outro sistema praticado no sambaqui do Rio Pinheiros (SC) permitia diminuir a espessura da parede a ser perfurada por rotação: um polidor manual, em forma de gume, marcava um risco profundo perpendicular ao eixo da peça, a partir do qual trabalhava a broca (Prous e Piaza 1977). No litoral catarinense de Joinville, o formato dos pingentes é mais freqüentemente de triangulo isóscele, com o orifício no ângulo mais fechado; não encontramos neste estado exemplos do polimento de uma faceta triangular superior - modus operandi talvez exclusivo de São Paulo. Algumas outras formas são encontradas esporadicamente: pingente oval no Macedo e Guaraguaçu III, no Paraná; retangular em Vila Nova (SP, Krone 1908) com $8,5 \mathrm{~cm}$ de comprimento e $1,5 \mathrm{~cm}$ de largura e no Linguado. Em Boguassu (SP), os Emperaire coletaram um adorno com cabeça larga e corpo pontudo, cujo polimento periférico eliminou as asperidades habituais das conchas de ostra (que apresentam estrutura folheada); a peça mede $13,3 \mathrm{~cm} \times 5 \mathrm{~cm}$. No interior de Minas Gerais e nas encostas da serra em Rio de Janeiro os pingentes foram encontrados em contexto cultural cerâmico; são trapézios de pequenas dimensões, geralmente com dois furos de suspensão. O exemplar carioca é assim descrito (Dias e Carvalho 1980): "espessa (cerca de $0,23 \mathrm{~cm}$ ) ... cuja base, convexa, tem $4,5 \mathrm{~cm}$ e a face oposta, menor, 2,2 $\mathrm{cm}$, tendo $3,2 \mathrm{~cm}$ de altura. No lado menor, existem duas perfurações com um cordel... de quatro fios, transpassado", fornecendo uma informação exclusiva sobre os elementos de suspensão pré-históricos, conservados num sítio da fase Mucuri. Em Minas Gerais, alguns exemplares isolados foram achados por H. Walter (1958) no sítio Marciano; também perto de Lagoa Santa, no abrigo de Lapinha II bis, a Missão Franco Brasileira encontrou dois exemplares, um dos quais quebrados, e o outro de forma triangular, com um furo só (Laming-Emperaire, Prous, Beltrão e Moraes 1975). Em sítio vizinho, o amador M. Banyai desenterrou 93 trapézios pequenos cada um com dois furos, associados a contas, em três colares (Banyai, informação pessoal). Possivelmente, as peças destes colares foram feitas com valvas de Diplodon, bivalva lacustre abundante na região que oferece uma bela superfície interna nacarada.

As contas nucleiformes (Figura $3 \mathrm{~m}$ ) são exclusivamente feitas com as conchas de pequenos gastrópodos de forma espiralada ou cilíndrica. As formas espiraladas são raras, aproveitando conchas de Natica, Cerithium, ou Polynices (20 - $30 \mathrm{~mm}$ ) cuja primeira volta é furada por pressão aplicada na face interna perto da abertura. $\mathrm{O}$ orifício é bastante irregular e se as peças não fossem encontradas em grande número (34 exemplares com o esqueleto de uma criança, no Morro do Ouro) poderia haver dúvidas sobre sua intencionalidade. Há outras ocorrências também no litoral de Joinville, nos sítios de Enseada (Beck et al. 1970), Forte São Luiz (Tiburtius 1960) e perto de Parati (Mello e Souza 1977). As contas nucliformes cilíndricas feitas a partir de conchas de tamanho médio $(3-4 \mathrm{~cm})$ são mais raras, embora encontradas em todo o litoral catarinense; são de Conus, Olivancillaria ou até Strombus pequeno, cujo ápice é 
perfurado e a columela parcialmente destruída para facilitar a introdução do cordão, que passa pela abertura natural. Mencionaremos os achados da Tapera, Laranjeiras (Rohr 1959: 23 e 1984), Forte Marechal Luz (Bryan 1977) e Enseada (Beck 1970, 1973). No interior do continente, Hurt e Blasi (1969) mencionam uma concha de origem marítima proveniente da gruta de Cerca Grande VI, perto de Lagoa Santa, sugerindo uma corrente de trocas entre o litoral e o interior desde o período pré-cerâmico. No entanto, são conchas muito menores de Neretina, Agaronia (ca $8 \mathrm{~mm}$ ) e, sobretudo, de Olivella $(11 \mathrm{~mm})$, que predominam na maior parte dos sítios em São Paulo, no litoral de Joinville, no interior de Rio Grande do Sul e até no triângulo mineiro (extremo oeste do estado de Minas Gerais). No Paranã são mais raras, perdendo em popularidada para os colares de vértebras de peixe - a não ser nos sambaquis do Macedo e da Ilha dos Ratos. No centro catarinense, só foram encontradas na Base Aérea e na Praia das Laranjeiras, sendo totalmente ausente na região de Laguna onde elementos sobre lasca mantém exclusividade. Estas pequenas contas tubulares eram agrupadas em colares e redes que comportavam centenas de elementos. Em Piaçaguera, um único esqueleto de criança era acompanhado por 618 Olivella verreauxi (Uchôa 1970); podiam alternar com pingentes de dentes de peixe e Olivellae, como no Morro do Ouro (Tiburtius, Bigarella e Bigarella 1954) ou acompanhar uma escultura zoomorfa dentro de um esconderijo localizado abaixo do sepultamento (Tiburtius e Bigarella 1960). Aparecem também em niveis pré-cerâmicos de três abrigos do Rio Grande do Sul: no cerrito Dalpiaz, ainda relativamente perto do mar (Miller 1969: 69), no abrigo do Macaco Branco (Mentz Ribeiro 1973:6) e no cemitério da Gruta Caveira, no vale do rio das Antas (Chmyz 1965). Enfim, vários exemplares estavam dentro de uma urna funerária desenterrada por um camponês de Patrocínio (Minas Gerais), juntamente com elementos de colar sobre lasca.

As contas sobre lasca (Figura 3na 3q) são geralmente discoidais e foram executadas quase que exclusivamente a partir de valvas de lamelibranquios. No litoral meridional são encontradas exclusivamente no centro e sul de Santa Catarina, em sambaquis e acampanhentos, assim como em raros cerritos do Rio Grande do Sul (entre 14 cerritos estudados por Schmitz 1976, somente três tinham um desses elementos de colar). Ocorrem também em sítios asfastados do litoral (cerrito Dalpiaz, abrigo Maximiano em Sâo Paulo; na região de Lapinha em Minas Gerais, ou na Gruta do Padre, em Pernambuco. Excluindo-se nos cerritos, compunham colares com numerosos elementos: havia 240 discos num sepultamento em Maximiano (Collet 1978), 675 formabam um colar no Rio Lessa (Beck e alii 1969). São discos regularizados por polimento de 5 a $23 \mathrm{~mm}$ de diâmetro, com uma espessura média de quase $2 \mathrm{~mm}$ no litoral. Na Lapinha, perto de Lagoa Santa, os 270 discos que compunham dois colares não ultrapassam $7 \mathrm{~mm}$ de diâmetro, havendo algumas de $3 \mathrm{~mm}$ somente, enquanto o furo atinge $2 \mathrm{~mm}$; a espessura é de $1 \mathrm{~mm}$. Em gruta utilizada como cemitério por ceramistas da região de Pains (ainda no centro de Minas Gerais), foi encontrado por Pinheiro um colar completo que comportava centenas de disco e um pingente. Outro conjunto de peças discoidais é proveniente do sítio do Vau, perto de Correntina (estado da Bahia). Contas semelhantes, coladas com resina, podem ser observadas em muitas 
coleções etnográficas, formando colares ou enfeitando máscaras. No século XIX, von den Steinen (1894) observou sua fabricação no Xingú, informando que cada elemento era polido isoladamente, o que representa um trabalho muito grande. Um estudo da homogeneidade das contas de colares permitiria verificar se não teria havido também o polimento conjunto, como era praticado até há pouco na Nova Caledonia, onde as contas, já presas no cordel, eram regularizadas por fricção lateral num calibrador. Nota-se que não se encontram em sítios pré-cerâmicos calibradores com canaleta que poderiam servir para formatar os elementos de um mesmo colar. Em compensação, são muito numerosos em sítios tupiguarani - nos quais adornos de concha estão raramente preservados.

O Museu do Estado do Ceará possui uma interessante coleção proveniente do litoral deste estado, que mostra várias fases de preparação desses adornos. Pequenos discos com cerca de $1 \mathrm{~cm}$ de diâmetro tinham sido formatados através de lascamento periférico; posteriormente se realizavam a regularização por polimento, a perfuração podendo ser anterior ou posterior ao polimernto (Figura 3n a 3o). Vimos o mesmo processo em sítios do Pantanal Matogrossense escavados por Migliaccio (2006) na região de Descalvados.

O Museu do Estado do Ceará também conserva peças provenientes do sítio de Canoa Quebrada no litoral cearense, com elementos de 1 a $2 \mathrm{~cm}$ de comprimento recortados em formato variado e polidos: há retângulos com quatro furos, como se fossem destinados a serem costurados, enquanto outros tem a mesma forma de molar de duas raízes, com dois furos (Figura 3s).

No sitio Guaiba (Rio de Janeiro), Heredia e seus colaboradores (1984) mencionam valvas muito duras de Callixta maculata cuja parte central tinha sido retirada, talvez para obtenção de discos. O caso das contas de colar retiradas da urna de Patrocínio (já mencionada) é, por enquanto, único: as conchinhas de Olivella (dois dos exemplares intactos permitiram a identificação) foram gastas por abrasão a partir do ápice e a partir da abertura, até sobrar somente um anel formado pela parte central da concha. A matéria prima era litorânea, mas a técnica de fabricação, totalmente original, talvez fosse particular ao interior das terras, onde raramente se preservaram objetos de concha.

Elementos recortados sem furo de suspensão

Nas coleções ou em prospecções encontramos artefatos cuja finalidade nos escapa totalmente e a respeito das quais sequer podemos levantar hipóteses. São conchas de bivalvas regularizadas ou seccionadas sem que seja formado um gume. Andreatta e Menezes (1975) mencionam três exemplares de Ostrea arborea seccionadas transversalmente, no sambaqui de Guaraguaçu B (Paraná). Quando estes elementos são menores, podeiam ser préformas de adornos. Um desses elementos, de formato retangular e com 3 bordas lascadas foi encontrado no 
acampamento de Cabeçudas (Santa Catarina). No acampamento do Tenório, uma valva de Anadara teve sua periferia lascada para ficar também com uma forma quadrangular. O lascamento foi provavelmente realizado sobre bigorna, provocando um retoque bem abrupto. Nas Lapas (abrigos) do Malhador e do Boquete, no vale do rio Peruaçu (norte de Minas Gerais) foram escavadas valvas espessas de Diplodon seccionada abruptamente em um ou vários bordos. Uma destas peças, possivelmente inacabadas, apresenta sua parte inferior intacta, enquanto a parte superior foi removida por lascamento. Isto poderia indicar as etapas de fabricação: uma formatação por lascamento sobre bigorna, seguido por uma regularização por polimento. Estes elementos poderiam ter sido colados em suportes como máscaras, como se verifica em artefatos etnográficos.

Tembetás (?) e objetos diversos

Algumas peças poderiam ser adornos labiais (Figura 3s a 3z). São columelas polidas de gastrópodos encontradas nos sambaquis catarinenses de Forte Marechal Luz (Bryan 1977) e de Cabeçudas perto de Itajaí (Schmitz e Verardi 1996). As sete peças de Cabeçudas parecem ter recebido um melhor acabamento que os exemplares de Forte Marechal Luz - estes, talvez ainda inacabados. A parte distal tem um botão enquanto a parte proximal, mais estreita, torna-se mais afiada na extremidade. A secção transversal destes artefatos, que não tivemos a oportunidade de ver, parece ser circular. Em seu estudo do sítio paranaense de José Vieira, A. Laming e J. Emperaire (1959) encontraram na camada tupiguarani um adorno de concha não descrito, que também poderia também ser um tembetá; provavelmente esta peça possa ser encontrada no Museu Paranaense. Uma columela lascada no Tenório e um fragmento de grande Olivancillaria do sítio do Buracão cuja columela tinha sido retirada são talvez indícios da fabricação de adornos labiais nesses dois acampamentos ricos em restos alimentares de moluscos.

Com Marcélia Marques visitei o que me pareceu ser um ateliê de fabricação de artefatos de concha em sítio erodido em dunas de Guajiru (município de Trairi, no litoral do Ceará) (Figura 3w). Em superfície se viam várias conchas de gastrópodes com sua espira recortada e columelas já separadas do resto da concha. No Museu do Estado se encontram artefatos feitos com columela de gastropodo marinho que também poderiam ser usados como tembetá - labial ou inserido na bochecha (Figura 3y).

No acampamento conchífero de Mar Casado e no sambaqui de Forte Marechal Luz havia vários objetos feitos de Olivancillaria brasiliensis, em diversos estágios de fabricação. Entre eles eram fatias discoidais de $7 \mathrm{~mm}$ de espessura e $30-40 \mathrm{~mm}$ de diâmetro retiradas transversalmente da região sub-apical. A parte distal da concha era lascada regressivamente ao redor da columela. O ápice era retirado por polimento e a região lascada, regularizada também por abrasão. Finalmente, a peça ficava totalmente lisa, com um pequeno orificio natural quase no centro, onde passava o corpo do animal. 
Em sítios do curso inferior do rio São Francisco (Xingó, estado de Sergipe) foram escavados vários adornos de conche, ente os quais o que parece ser uma pulseira feita coma a parte mesial de uma concha de grande gastrópode.

É importante ficar atento às possibilidades de ocorrências naturais se parecerem com o trabalho humano. Existem gastrópodos marinhos carnívoros (Murex, por exemplo) capazes de serrar ou perfurar a concha das outras espécies. O furo pelo qual o caramujo alcança as partes moles é perfeitamente circular e liso; seu de diâmetro mal alcança $2 \mathrm{~mm}$ de diâmetro. A dimensão diminuta e a perfeição do resultado são suficientes para diferenciar a ação do animal das perfurações de origem antrópica. Outras marcas de trabalho podem levar a interpretações equivocadas; C. del Rio Garcia (comunicação pessoal) nos mostrou que a lesma de Thais é muito difícil de ser retirada da concha, mesmo depois de morta por aquecimento ao fogo. Desta forma, para poder consumi-la, seria necessário fraturar o envólucro. Nestas condições, pode haver um padrão de fratura decorrente do conhecimento da melhor forma de extrair o animal nos grupos que se alimentavam de Thais haemastoma (esta espécie predomina no sambaqui do Moa). Assim, o arqueólogo poderia observar a criação de formas regulares que são, de fato, devidas à ação humana, mas que não implicam uma modificação destinada a torna-las aproveitáveis como instrumento. Lima e Silva (1984), por sua vez, mencionam "cortes transversais na região da espira e volta do corpo" para quebrar as conchas de Astraea e retirar a lesma, mas não sabemos se esta interpretação é fundamenta pela prática. Outros predadores provocam a quebra das valvas, tais como as arraias do gênero Myliobatis, mas é pouco provável que o homem pré-histórico tenha trazido estas conchas fraturadas sem interesse para seu acampanhamento.

Não podemos deixar de considerar que algumas conchas raras poderiam ter sido coletadas pela simples curiosodade: seria o caso de exemplares de Terebra (sambaqui da Conquista) e Cyprea zebra.

\section{Acompanhamento funerário}

A maior parte dos artefatos de concha foi encontrada em sepultamentos particularmente os adornos; segundo Kokler (2008), 70\% das contas de concha encontradas pelos arqueólogos no sambaqui de Jaboticatubas II estavam em contexto funerário; neste sítio, também instrumentos acompanhavam os mortos: seis raspadeiras estavam associadas a esqueletos humanos. Cerca de 650 contas formavam provavelmente uma toca em rede, que cobria a cabeça da "Miss Sambaqui" de Piaçaguera datada em 4.000 anos. Mais ao norte, os sítios do litoral dos Lagos de Rio de Janeiro não forneceram esta profusão de adornos de concha; mesmo assim, dezenas de conchas perfuradas foram encontradas nos sambaquis do Moa e de Saquarema (Guimarães 2007). Na mesma região, dois dos três esqueletos escavados no sambaqui de Itaunas (o mais antigo da região, datado em 5.700 BP) apresentavam duas valvas de Lucina pectinata, uma em cada orbita (eadem, ibidem). Nem todas as conchas compunham adornos ou tinham sido modificadas. Por vezes trata-se apenas de conchas de espécies raras, ou especialmente bonitas. Segundo Amenemori (2005), em três dos 48 dos 
sepultamentos do Mar Virado foram encontradas valvas de Spondylus americanus; outro continha uma concha de Cyprea zebra; três corpos estavam acompanhados por exemplares de Astrea sp. - uma concha menos chamativa, mas que poderia ter um valor simbólico especial.

Embora menos numerosas do que no litoral, não faltam conchas e artefatos conchíferos em sepultamentos nos sítios interioranos. No período pré-cerâmico mencionaremos o abrigo de Santana do Richo (perto de Lagoa Santa), no qual escavamos dezenas de sepultamentos datados do início do Holoceno; em todos aqueles que parecem ter sido realizados durante a estação úmida (presença de vegetais associados tais como o pequi - Caryocar brasiliense) se encontram conchas de Megalobulimus queimadas (jogavam-se brasas ainda quentes nos corpos). Na Toca (abrigo) do Enoque (estado do Piauí), vários corpos foram enterrados durante o Holoceno médio (5.900 BP). Perto da mão esquerda de um adulto (sepultamento 1) estavam uma concha, uma plaqueta de pigmento mineral e uma lasca de quartzo. Juntas da pelve coberta de pigmento vermelho havia quatro conchas de Strophocheilideae, assim como contas perfuradas que poderiam ter formado uma pulseira (Guidon e Luz 2017). Sobre o joelho esquerdo e na parte proximal do fêmur esquerdo do sepultamento 3 estavam "peças feitas de barro, decoradas com conchas ou pedaços de osso animal".

Ainda no nordeste do país, o cemitério do período pré-cerâmico tardio da Furna do Estrago (estado de Pernambuco) foi escavado por Lima, que contabilizou 667 elementos de adorno - sobretudo contas de osso, mas também de concha. Uma mulher jovem estava enterrada com nove contas de Olivella cuja concha tinha sido trazida desde o litoral (distante $200 \mathrm{~km}$ ) e 62 dentes de felinos perfurados (Lima 1999).

Os ceramistas dos últimos dois milênios também mantiveram, em todo o Brasil, a tradição de enterrar adornos de concha com alguns dos seus mortos. Por exemplo, na urna em cerâmica $n^{\circ} 1$ da Toca do Gongo I (Piaui), havia uma concha de bivalva abaixo do maxilar inferior do esqueleto (Maranca 1976). Os tupiguarani (prováveis ancestrais de populações guarani) de Santa Catarina também prezavam os adornos de concha. Contas discoidais de colar foram encontradas em urnas com esqueletos adultos e infantis perto de Imbituba (litoral central de Santa Catarina), enquanto "um conjunto de pingentes de concha polidas, em forma de palitos com furo central" estava dentro de uma urna no município de Jaguaruna, no litoral meridional do mesmo estado (comunicação pessoal de Lavina).

Acreditamos que poderia ter havido uma relação entre os caramujos "ctonianos" (enterram-se na estação seca, muito marcada no Brasil central e nordestino, para "reviver" durante as chuvas) da família dos Strophocheildeae e os rituais da morte. Isto transparece, por exemplo, na mitologia Bororó (Albisetti e Venturelli 1969). Um mito mostra o Megalobulimus - denominado Ruwo por estes indígenas - lutar vitoriosamente contra a onça, cujos dentes deixam, porém, suas marcas na concha (as estrias de crescimento). Acontece que, na mitologia Bororó, o jaguar é sempre responsabilizado 
pela morte de qualquer pessoa; por isto, o companheiro morto deve ser vingado em uma caçada coletiva, durante a qual uma onça deve ser morta. Ora, Ruwo é usado para preparar a madeira do arco, instrumento da morte do felino. No mito, o molusco fica, portanto, vinculado à vingança dos homens, depois de ter escapado da fera. É possível, portanto, que as conchas selecionadas para seguir o morto sejam o reflexo de uma crença da qual o mito Bororó seria o último eco. Melatti (1986), por sua vez, assinala a relação entre a morte e os colares de concha entre os atuais índios Marubo, que evitam fabricar contas de concha no periodo de luto.

\section{Indicação de movimentos de pessoas e/ou de matérias-primas}

A fácil diferenciação entre as espécies de moluscos marítimos, fluviais e terrestres permite saber quando conchas oriundas do litoral marinho foram transportadas para o interior das terras e a distância mínima (em linha reta) que percorreram. Infelizmente, no caso brasileiro, isto não permite saber se as populações que as abandonaram nos sítios arqueológicos as trouxeram ou se dependiam de intermediários. Estes poderiam ser viajantes que percorriam toda a distância de uma vez, tais como iocorria difusão de Spondylus que mercadores especializados do Equador exportavam para o litoral peruano (Martins 2010), sejam populações intermediárias pelas quais os objetos passavam sucessivamente, tal como ocorria no kula das Ilhas Trobriand (Malinowski 1922). Não há, nos sítios préhistóricos brasileiros, indícios de um transporte sistemático entre o litoral e interior do continente, mas alguns exemplos evidenciam certa mobilidade. Na encosta da Serra do Mar, no Rio Grande do Sul, conchas marinhas foram encontradas a $30 \mathrm{~km}$ do litoral mais próximo, no abrigo cerrito Dalpiaz. A distância não é muito grande, mas já é significativa, pois o abrigo encontra-se numa zona ecológica de tipo interiorano (Miller 1969: 102). No mesmo estado, em Bom Jardim Velho, conchas marinhas foram encontradas a mais de $130 \mathrm{~km}$ do oceano, no vale do rio Cai em ocupação de abrigo pré-cerâmica (Mentz-Ribeiro 1972). Outros achados similares ocorreram, desta vez em niveis cerâmicos (cultura tupiguarani) nos vales dos Rios Pardo e Pardinho, em zonas de altitude distantes mais de $250 \mathrm{~km}$ do mar (MentzRibeiro 1978). Em ambos os casos, a existência de exportação de produtos do litoral para o interior ao longo do curso do rio Jacui e dos seus afluentes é atestada por outros achados (por exemplo, zoólitos de pedra).

Mais para o norte, a Serra do Mar criava uma inquestionável barreira orográfica e cultural entre os moradores da costa e as populações dos estados desde Santa Catarina até Minas Gerais. Mesmo assim, vimos que alguns achados de concha marinhas em Minas Gerais indicam a existência de contatos - possivelmente pelo vale do Rio Doce. Durante as escavações dirigidas por W. Hurt no abrigo II de Cerca Grande (Lagoa Santa) foi encontrada uma concha tubular perfurada de gastrópodo marinho com 3,2 cm de comprimento, que o relatório (Hurt e Blasi 1969) identifica como Olivella. Não datada, esta conta teria, pois, viajado um minimo de $350 \mathrm{~km}$, transpondo a Serra do Mar, e cerca de 650 (dos quais quase uma centena por terra) se tivesse chegado pelo 
vale do Rio Doce. De fato, se for mesmo uma Olivella, seria de uma espécie bem maior que aquela (Olivella verreauxi) que normalmente fornecia contas de colar no litoral; de qualquer forma, não há nenhuma concha tubular nos rios e lagoas de Minas Gerais; portanto, o objeto é efetivamente de origem marinha. Não se trata de um achado totalmente isolado, pois a malacóloga N. de Souza Moreira identificou a nosso pedido como Olividae as conchas que compunham o colar encontrado dentro de uma urna funerária em Patrocinio (MG). Ainda neste caso, uma grande distância (mais de $500 \mathrm{~km}$ em linha reta) separa o local do litoral, e Patrocínio é muito mais distante do Rio Doce que Lagoa Santa.

Ainda em Minas Gerais, o amador Simão Ribeiro Pires escavou, em meados do século XX, a Lapa Pintada de Montes Claros, onde encontrou um colar de concha. Segundo seu depoimento, que registramos pouco antes da sua morte, uma amostra teria sido identificada por zoólogos do Museu Nacional como sendo de uma espécie cujo habitat é exclusivamente amazônico. Infelizmente, a coleção foi dispersa depois da sua morte e não pudemos verificar o que seria o primeiro sinal concreto de relações entre o planalto central de Minas Gerais e a bacia amazônica durante o período pré-histórico.

Já vimos que, muito mais ao norte, no abrigo da Furna do Estrago -distante 170 $\mathrm{km}$ em linha reta do litoral de Pernambuco, uma jovem mulher estava enterrada com nove contas de Olivella. Sabe-se que, até o século XVI, os indígenas que moravam na costa iam sazonalmente coletar as nozes de caju no Brejo da Madre de Deus, onde se encontra a Furna do Estrago. Nota-se que não há fortes relevos para vencer, mas também não existe rio que facilite a penetração para o interior.

\section{Datação}

Finalmente, as conchas podem ser datadas, particularmente pelos métodos de urano tório $\left({ }^{234} \mathrm{U} /{ }^{230} \mathrm{Th}\right)$ e de radiocarbono $\left({ }^{14} \mathrm{C}\right)$. Deve-se frisar, contudo, que para as datações radiocarbônicas, as conchas apresentem vários problemas em relação às matérias vegetais ou ao colágeno dos ossos: a solubilidade que causa trocas com o meio, a recristalização da aragonita em calcita e a necessidade de correção em função do reservatório marinho podem falsear os resultados.

\section{Conclusão}

Entre os pré-historiadores, os sambaquis do Brasil ficaram famosos pela sua monumentalidade. Existem amontoamentos de concha em quase todas as regiões litorâneas (marítimas e lacustres) da terra: litoral atlântico europeu desde o Portugal até o mar do Norte, África do norte, Sénégal, Camboja, Japão, Austrália, etc. Contudo, em lugar algum alcançam as dimensões dos grandes sambaquis do estado meridional de Santa Catarina (até $30 \mathrm{~m}$ de altura) ou mesmo do litoral amazônico (até $8 \mathrm{~m}$ ). Forneceram um material de construção não apenas para os pré-históricos, mas para os colonizadores portugueses, que das conchas dos 
sambaquis faziam cal para suas edificações (por exemplo, a catedral de Salvador); esta exploração continuou até os anos de 1970 no sul do Brasil, onde as conchas também pavimentavam estradas ou eram moídas para servir de complementos alimentares para as galinhas poedeiras.

Os moluscos forneciam um complemento alimentar significativo para as populações pré-históricas assim como aos atuais moradores pobres do litoral. Seu papel como matéria-prima para adornos é também conhecido. As conchas proporcionam gumes para cortar, para raspar e descascar e, se necessário, para furar. Vimos, através do exemplo do sambaqui do Moa, que um terço dos instrumentos reconhecidos podiam ser feitos de concha. Não se encontraram no Brasil instrumentos pesados como as lâminas de machado e de goivas feitas com valvas de Strombus gigas, registradas na Venezuela (Cruxent e Rouse 1958), o que pode ser explicado pela ausência desta espécie no litoral meridional do Brasil; como poucos sítios do litoral amazônico foram escavados em grande superfície, talvez artefatos feitos com grandes conchas apareçam no futuro.

Vimos também que os moluscos devem ser observados com cuidado nas escavações realizadas em abrigos. Podem confundir os arqueólogos invadindo espontaneamente espaços domésticos produzindo falsas marcas de poste ou dando uma impressão equivocada de que formavam uma parte significativa da alimentação. De forma mais positiva, podem informar indiretamente sobre estruturas desaparecidas. Um belo exemplo é fornecido pelo sítio do Lazaret, na França, onde H. de Lumley escavava ocupações datadas do Pleistoceno médio (cerca de 150.000 anos antes do presente). Três espaços livres dos detritos normalmente espalhados no interior de uma suposta estrutura de habitação apresentavam ossos de pata e garras de animais de pelo e minúsculas conchas de Bittium e Littorina que vivem no meio de algas marinhas. Os arqueólogos (Lumley e Boone 1976) interpretaram estes vestígios como a indicação que haveria nestes espaços uma acumulação artificial de algas (no meio das quais teriam vindo as conchas) cobertas por peles; tratar-se ia, portanto, de camas pré-históricas. Outro exemplo inspirador é do sítio de Waylands Smithy I na Inglaterra, no qual gastrópodos necrófagos encontrados em sepultura demonstraram que os corpos tinham sido depositados ainda com as carnes e que o túmulo não tinha sido preenchido logo com sedimento (Evans 1972).

As conchas encontradas em sítios fornecem também preciosas informações paleoecológicas; as ostras de mangue que predominam em vários sambaquis da região de Laguna evidenciam a presença deste tipo de vegetação nesta região quatro milênios atrás; ora, os manguezais recuaram para o norte nos últimos milênios. O estudo das estrias de crescimento das conchas marítimas, assim como a presença de gastropodos terrestres em estruturas nas regiões com estação seca marcada indicam a estação da sua coleta, contribuindo a informar sobre a sazonalidade ou a permanência das populações em determinados sítios. No estado de Minas Gerais também foram registradas modificações faunísticas significativas, com a substituição de Megalobulimus yporangus 
por Megalobulimus oblongus (mais adaptado ao calor) e o desaparecimento de Naesiotus na Lapa Vermelha IV de Lagoa Santa; notamos também desaparecimento de outro gastrópode no início do Holoceno na Lapa do Dragão (norte do estado, próximo a Montalvânia) etc..

Finalmente, as conchas podem ser datadas, particularmente pelos métodos de urano tório $\left({ }^{234} \mathrm{U} /{ }^{230} \mathrm{Th}\right)$ e de radiocarbono $\left({ }^{14} \mathrm{C}\right)$. Deve-se frisar, contudo, que para as datações radiocarbônicas, as conchas apresentem vários problemas em relação às matérias vegetais ou ao colágeno dos ossos: a solubilidade que causa trocas com o meio, a recristalização da aragonita em calcita e a necessidade de correção em função do reservatório marinho podem falsear os resultados.

De qualquer forma, a análise das conchas de moluscos se mostra rica em possibilidades para reconstituir a vida das populações do passado, não devendo mais ser suas potencialidades subestimadas.

Agradecimentos: Agradecemos Rodrigo Lavina, que forneceu informações sobe sepultamentos em urna inéditos do estado de Santa Catarina.

\section{Bibliografia citada}

Albisetti, C. e Venturelli, A.

1962 Enciclopédia Bororo. Ed. Salesianas, Campo Grande.

Amenomori, S. Nami

2005 Paisagem das Ilhas - as ilhas da paisagem. A ocupação dos grupos pescadores-coletores pré-históricos do litoral norte do estado de São Paulo. Tese de Doutorado, Universidade de São Paulo (USP).

Andreatta, M. e Meneses, M. J.

1975 Dados parciais das pesquisas no sambaqui B de Guaraguaçu, Revista do Museu Paulista, NS, XXII: 135-155.

Bandeira, A. Marques

2008 As ocupações pré-históricas no litoral Maranhense - um estudo arqueológico sobre o sambaqui do Bacanga, na Ilha de São Luis do Maranhão, Dissertação de Mestrado, São Paulo, USP.

Beck, A., Araujo, E. Medeiros, Silva, V. H., Thiago, M. de S. e Fossari, M. D 1969 Estudos do sambaqui do rio Lessa Anais do Museu de Antropologia, Florianópolis, II: 139-206.

Beck, A. Araujo e Duarte G.M.

1970 Síntese da arqueologia do litoral norte de Santa Catarina Anais da Universidade Federal de Santa Catarina, III: 23-24. 
Beck, A.

1973 A variação do conteúdo cultural dos sambaquis - Litoral de Santa Catarina, Tese USP.

Beltrão, M. da C. de M.C.

1976 Documentos sobre a pré-hist6ria dos estados do Rio de Janeiro e Guanabara (1500-1963) Revista do Museu Paulita, São Paulo, Série Arqueologia, 2: 13-79.

Bianchini, G.F.; Gaspar, M.D.; DeBlasis, P.; Scheel-bert, R.

2011 Processos de formação do sambaqui Jabuticabeira-II: interpretações através da análise estratigráfica de vestígios vegetais carbonizados. Revista do Museu Arq. e Etn., São Paulo, 21: 51-69.

Biocca G.; Hoge, A. e Schreiber, G.

1947 Contribuições ao estudo de alguns sambaquis da ilha de Santo Amaro (Estado de São Paulo). Revista do Museu Paulista São Paulo, Nova Série, I: 153-170.

Bryan, A. 1977. Resumo da arqueologia do sambaqui do Forte Marechal Luz, Arquivos do Museu de História Natural da UFMG, Belo Horizonte, 2: 9-30.

Calderón

1964 O sambaqui da Pedra Oca Salvador, Universidad da Bahia, Instituto de Ciências Sociais 2: 89.

Carvalho, E.

1984 Estudo arqueológico do sítio Corondó - Missão 1978, IAB, Rio de Janeiro, série Monografias, 2.

Chmyz, I.

1965 Prospecções arqueológicas no Vale do Rio das Antas, Rio Grande do Sul, Brasil Acta Prehistorica, Buenos Aires, 5/7: 35-62.

Collet, G.

1978 Notas prévias sobre sondagens efetuadas num abrigo sobre rocha no vale do rio Maximiano-Iporanga-SP Sociedade Brasileira de Espeleologia, Primeira parte: $47 \mathrm{p}$. Segunda parte. 26 p. mimeografado

Collet, G. Ch. e Guimaraes, C.M.

1977 Primeiro informe sobre os sambaquis fluviais da região de Itaoca (SP) “Resultado da sondagem do sambaqui Januário Arquivos do Museu de História. Natural da Universidade Federal de Minas Gerais, Belo Horizonte, UFMG, 2: 36-50.

Cruxent, J.M. e Rouse, I.

1958-1961 An archeological chronology of Venezuela, vol. I: 277 p. vol. II: Arqueologia e cronologia de Venezuela, 255 p. Washington, Pan American Union. 
DeMasi, M. A.

2001 Pescadores e coletores da costa sul do Brasil Pesquisas, Antropologia 57, São Leopoldo.

Dias, O. y Carvalho, E.

1980 A pré-história da Serra Fluminense e a utilização das grutas do estado do Rio de Janeiro Pesquisas, São Leopoldo, Antropologia 30: 43-86.

Duarte, $P$.

1968 O sambaqui visto através de alguns sambaquis in: Pré-História Brasileira, IPH-USP, p. 44-142.

Emperaire, J. e Laming, A.

1956 Les sambaquis de la côte méridionale du Brésil, campagnes de fouilles 1954-1956, Journal de la Société des Américanistes, Paris, NS, 45: 5-163.

Erlandson, $\mathrm{M}$.

1988 The role of shellfish economies. American Antiquity 53 (1): 102-109

Errico, F. d' - e alii,

2009 Additional evidence on the use of personal ornaments in the Middle Paleolithic of North Africa. Proceedings of the National Academy of Sciences of the United States of America, 196 (38): 116051-116056.

Estevão, C.

1938 O ossuário da gruta do Padre em Itaparica, e algumas notícias sobre os remanescentes indígenas do Nordeste, Recife, Fronteiras.

Evans, J. G.

1972 Land Snails in Archaeology. Seminar Press: London e New York.

Figuti, L.

1992 Les sambaquis Cosipa (4000 à 1200 ans BP): Étude de La subsistance chez les peuples préhistoriques de pêcheurs-ramasseurs de bivalves de la côte centrale de l'Etat de São Paulo, Brésil tese de Dr., Institut de Paléontologie Humaine, Paris.

Gaspar, M., M. D.

2003 Aspectos da organização social de um grupo de pescadores, coletores e caçadores: região compreendida entre a Ilha Grande e o delta do Paraíba do Sul, estado do Rio de Janeiro. Revista Pesquisas, Antropologia 59.

Greber, E.

1938 Tratado de cerâmica. Barcelona: Gustavo Gili Editor. 


\section{Guidon, N.}

1964. Nota prévia sobre o sambaqui Mar Casado in: Homenaje a Fernando MarquezMiranda, Madrid, Univ. de Madrid y Sevilla, p. 176-204.

Guidon, N. e Luz, M. de F. da

2017. Sepultamentos na Toca do Enoque (Serra das Confusões-Piauí), FUMDHAMentos, VIII: 116 - 123.

Guidon, N. e Pallestrini, L.

1962 Estudo da indústria de Mar Casado, Anhembi, São Paulo 47 (139): 49-60.

Guimarães, M. B. da Costa

2007 A ocupação pré-colonial dos Lagos-RJ: sistema de assentamento, relações inter-societais entre grupos sambaquianos, grupos ceramistas Tupinambá e da Tradição Una, Tese Dr. USP.

Heredia, O.R.; Gatti, M.P.; Gaspar, M.D. e Buarque, A.M.G.

1984 Assentamentos pré-históricos nas ilhas do litoral centro-sul brasileiro: o sítio Guaíba (Magaratiba, RJ) Revista de Arqueologia 2(1): 13-50.

Hoch, E. e Prous, A.

1985 A contribuição de P. V. Lund à arqueologia europeia e brasileira, Arquivos do Museu de História Natural 10: 170-176.

Hurt, W. e Blasi, O.

1960 O sambaqui do Macedo. S. 52/3. Curitiba, Conselho de Pesquisa Univ. do Paraná, Arqueologia 2.

1969 O projeto arqueológico Lagoa Santa-Minas Gerais, Brasil: nota final Arquivos do Museu Paranaense, NS, Arqueologia 4, Curitiba.

Kern, A.

1989 Pescadores-coletadores pré-históricos do litoral norte do Rio Grande do Sul, Documentos 3: 107-122.

Klokler, D.

2008 Food for body and Soul - Mortuary ritual in shellmounds (Laguna, Brazil), PhD., Univ. of Arizona.

Kneip, L.; Crâncio, F.; Santos, C., Magalhães e R. e Mello, E.

1997 O sambaqui do Saco e de Madressilva - Saquarema, RJ, Documentos de trabalho, 4, 47.

Krone, $\mathrm{R}$.

1908 Informações Ethnogaphicas do Vale do Rio Ribeira de Iguape, Exploração do Rio Ribeira de Iguape, Comissão Geographica do Estado de São Paulo: 23-34. 
Laming, A. e J., Emperaire.

1959 A jazida José Vieira: Um sítio Guarani e pré-cerâmico do interior do Paraná, Arqueologia, 1 (1).

Laming-Emperaire, A.; Prous, A.; Moraes, A. e Beltrão, M.

1975 Grottes et abris de Ia région de Lagoa Santa, Minas Gerais, Brésil Cahiers d'Archéologie d'Amérique du Sud, 1, EPHE, Paris.

Leonardos, O.H.

1938 Concheiros naturais e sambaquis Serviço de fomento da produção mineral, Rio. 109 1939. Os sambaquis do litoral de São Paulo. Mineração e Metalurgia 3 (17): 271-277

Lima, J.

1999 Adornos da população pré-histórica do sítio Furna do Estrago, Brejo da Madre de Deus, Pernambuco Anais da $X^{a}$ reunião da SAB, Recife, UFPE.

Lima, T. A.

1991 Dos mariscos aos peixes: um estudo zooarqueológico de mudança de subsistência na préhistória do rio de Janeiro, Tese, USP, São Paulo.

Lima, T. A. e Silva, R. C. P. da.

1984 Zoo-arqueologia: alguns resultados para a pré-história da Ilha de Santana Revista de Arqueologia, Belém (2): 10-40.

Lumley, H. de - e Boone, Y.

1976 Les structures d'habitat au Paléolithique Inférieur in La Préhistoire Française I (1):

625-643. CNRS, Paris.

Malinowski, B.

1922 Argonauts of the Western Pacific (consultado na edição de 1961, New York, Dutton)

Martins, G. Bertazoni

2010 O papel do "dinheiro primitivo" na economia Inca, Mestrado, São Paulo, USP, 162 p.

Melatti, S.

1986 Simbolismo dos adornos corporais Marúbo Revista do Museu Paulista, São Paulo, NS. 3: 7-14.

Migliaccio, M. C.

2006 O doméstico e o ritual no cotidiano Xaray no Alto Paraguai até o século XVI, tese de Doutorado, São Paulo, USP.

Miller, E. Th.

1969 Resultados preliminares das pesquisas nos sítio pré-cerâmico RS-LN-01: Cerrito 
Dalpiaz (abrigo sob rocha), Iheringia, série Antropologia, Porto Alegre, 1: 43-112. 2009 Pesquisas arqueológicas no Pântanal do Guaporé-RO, Brasil: a sequência seriada da cerâmica da Fase Bacabal, in: B. Megger (org.) Arqueologia interpretativa. O método quantitativo para estabelecimento de sequências cerâmicas: estudos de caso, Porto Nacional, Universidade do Tocantins (UNITINS).

Pallestrini

1964 A jazida do Buracão - km 17 da estrada Guarujá-Bertioga in: Homenaje a Fernando Marques-Miranda, Madrid, pp. 293-322. Universidades de Madrid y Sevilla: España.

Plens, C.

2007 Sítio Morães: uma biografia não autorizada, Tese de Doutorado, São Paulo, USP, 240.

Prous, A.

1986/90 Os moluscos e a arqueologia brasileira Arquivos do Museu de História Natural, 11: 241-300.

1992 Arqueologia Brasileira, Brasília, UNB, 614p. (uma versão modificada e atualizada está atualmente no prelo, pela editora Carlini e Caniato/TantaTinta - Cuiaba).

2009 Artefatos e adorno sobre suportes de origem animal, vegetal ou mineral (concha, casca de ovo, dente, osso, cera, fibras vegetais e calcita) in: Prous, A. e Rodet, M. J. (coord.) Arqueologia do Vale do Rio Peruaçu, e Adjacências, Arquivos do Museu de História Natural UFMG, 19: 371-413.

Prous, A. e J. T., Barros.

1977 Arqueologia no Brasil filme 35mm, Embrafilme/UFMG.

Prous, A. e W., Piazza

1977 L'Etat de Santa Catarina Documents pour la préhistoire du Brésil méridional, Cahiers d'Archéologie d'Amérique du Sud, Paris, 4.

Rauth, J.W.

1968 O sambaqui do Gomes S. 11. B Conselho Federal de Pesquisa, Curitiba, Universidade do Pararaná.

1969 Nota prévia sobre a escavação do sambaqui do rio São João PRONAPA II: 75-94. 1971 Nota prévia sobre a escavação arqueológica do sambaqui do Godo PRONAPA 1 1971 Nota prévia sobre a escavação do sambaqui do Porto Mauricio, Programa Nacional de Pesquisas Arqueológicas (PRONAPA), I: 47-54. Belém.

1969. Nota prévia sobre a escavação arqueológica do sambaqui do Godo PRONAPA III: 75-98, Belém.

1971. Nota prévia sobre a escavação do sambaqui do Ramal PRONAPA IV: 115-132.

1974. Escavações arqueológicas do sambaqui do Guaraguaçu II. S. 28 R Revista de Antropologia 2: 27-196, Paranagua.

1974 Nota prévia sobre a escavação do sambaqui do rio Jacarei PRONAPA V: 91-104. 
1974 Escavações arqueológica do sambaqui do Guaraguaçu 11. S. 28 R. Revista de Antropologia 2: 27-196.

Ribeiro, B.

1988 Dicionário do artesanato indígena, Belo Horizonte, Itatiaia/EdUSP, 343 p.

Ribeiro, P.A.

1972 Sitio RS-C 14: Bom Jardim Velho (abrigo sob rocha) - Nota Prévia, Iheringia, Museu Riograndense de Ciências Naturais, Antropologia 2: 15-58

Rohr, J. A.

1958/62 Pesquisas paleo-etnográficas na Ilha de Santa Catarina (I-IV). Pesquisas 3: 199-266.

Rohr e, A.

1969 O sítio Arqueologico da Armação do Sul, Pesquisas, 20: 135-138.

Santos, E.

1955 Os Moluscos Rio de Janeiro, F. Briguiet ed.

Schmitz, P. I.

1976 Sítios de pesca lacustre em Rio Grande, RS, Brasil. Tese de Livre Docência, mimeografada.

Schmitz, P. I. , Rogge, J. H.; Rosa, O. e M., Beber.

1998 Aterros indígenas no Pantanal do Mato Grosso do Sul. Pesquisas 54: 1-271

Schmitz, P. I. e Verardo, I.

1996. Cabeçudas: um sítio Itararé no litoral de Santa Catarina, Pesquisas, Antropologia 53: $125-181$.

Schorr,

1976 Análise dos restos de alimentaçãodas gruts do Projeto Paraíba, Arqueologia de Goiás em 1976, Univ. Cat. De Goias/Instituto Anchietano de pesquisas, pp. 96-103.

Silva, S. F. S.

2005. Arqueologia das práticas mortuárias pré-históricas do litoral do estado de São Paulo, Tese Dr. USP.

Silveira, M. I.

1994. Estudo sobre estratégias de subsistência de Caçadores Pré-Históricos do sítio Gruta do Gavião, Carajás (Pará), Dissertação de Mestrado, São Paulo, USP. 
Solá, M. E. e L., Jokl.

1978 Estudo do valor nutritivo dos Strophocheilidae, Arquivos do Museu de História Natural da UFMG, Belo Horizonte, 3: 173-178.

Souza, G. S.

1938 Tratado descritivo do Brasil em $15873^{\text {a }}$ edição, São Paulo, Ed. Nacional.

Thevet, A.

1558 Les Singularitez de la France Antartique, Anvers, Plantin ed.

Tiburtius, G. e J. J. Bigarella

1951 Nota prévia sobre a jazida paleoetnográfica de Itacoara, Joinville, Santa Catarina, Arquivos de Biologia e Tecnologia. 5/6: 315-346.

1960. Objetos zoomorfos do litoral de Santa Catarina e Paraná Pesquisas, São Leopoldo, Antropologia 7: 51.

Tiburtius, G.

1960 Schmuckgegenstande aus dem Muschlbergen von Paraná und Santa Catarinam Sudbrasilien, Pesquisas, São Leopoldo, Antropologia 4: 60.

Tiburtius, G.

1966 O sambaqui da Conquista (nº9), Boletim Paranaense de Geografia, 18/20: 7- 126.

Tiburtius, G., Bigarella, J. e I. K. Bigarella.

1954 Contribuição ao estudo do litoral norte de Santa Catarina 11 - sambaqui do Rio Pinheiros, Arquivos de Biologia e Tecnologia, Curitiba, IX: 141-197.

Uchoa, D. P.

1970 Nota prévia sobre os sepultamentos de Piaçaguera Estudos de Pré-História Geral e Brasileira, São Paulo, IPH-USP: 487-491.

Walter, H.V.

1958 Arqueologia na regiãa de Lagoa Santa, Minas Gerais: Indios pré-colombianos dos abrigosrochedos Rio de Janeiro, SEDEGRA. 